\title{
A template approach to pragmatic constituent order variation in modern Northern Mansi
}

Mansi belongs to the Ob-Ugrian branch of the Uralic language family. Northern Mansi constituent order and its pragmatic variation have not been examined comprehensively until now. This lack is filled in this article, by syntactic-pragmatic template analysis, using a new model of $9+1$ templatic slots, which are filled with syntactic or pragmatic functions. Thus, this study is also an attempt to combine both pragmatic and syntactic levels in the same template analysis. Moreover, Rombandeeva's $(1979 ; 1984)$ earlier observations on Northern Mansi word order, and those of other scholars, are compared to those drawn here from contemporary data.

1. Introduction

2. Information structure in Mansi

3. Word order and constituent order as a typological question

3.1. Perspectives on word-order typology

3.2. Syntactic template as a device for describing constituentorder variation

4. Research data and implementation of the analysis

4.1. Research data

4.2. Implementation of the analysis
5. Linear placement of syntactic functions in my data 5.1. On verb-finality

5.2. Placement of the subject

5.3. Placement of DOs, IOs and directional adverbials

5.4. Placement of adverbials: time, location and manner

5.5. Placement of agent adverbials, negation particles, nominal predicates and infinitives

5.6. Question words and interrogative structures

6. Results, conclusions and further questions

\section{Introduction}

In this article, I provide a syntactic-pragmatic linearization template for Northern Mansi constituent order. To do this, I integrate a pragmatic level into syntactic template analysis. Template analysis is a variable device which is used to analyse linearization and which has been defined, for example, by Good (2016). The idea of writing this article arose from the lack of sufficient knowledge regarding Mansi constituent order. Mansi is an 
indigenous language spoken in Western Siberia. It belongs to the Ob-Ugrian branch of the Uralic language family. There are still approx. 1,0oo living speakers of Mansi. Three of the four main dialects have practically vanished; only the Northern dialect is still spoken. Many basic details of Mansi grammar have still not been researched at all, or not comprehensively.

Like all Uralic languages, Mansi is an agglutinative language with a rich variety of inflectional and derivational suffixes. It also has postpositions and verbal preverbs. The Northern Mansi case system consists of an unmarked nominative case and five case endings: locative, lative, ablative, instrumental and translative. Unlike many Uralic languages, Mansi has no genitive case: possession and other genitive-related relations are expressed with possessive suffixes. There are three numeral categories in Mansi: singular, dual and plural. All three numbers occur both in verb and noun inflection.

Northern Mansi is a language with Differential Object Agreement (DOA), which is a phenomenon closely related to Differential Object Marking (DOM, see e.g. Bossong 1985; Aissen 2003), and this is conditioned by pragmatics (Dalrymple \& Nikolaeva 2011; Virtanen 2014; Sipőcz 2016). According to some recent studies (Skribnik 2001; Virtanen 2015; Sosa 2017), in the information structure ${ }^{1}$ of the Ob-Ugrian languages, pragmatic functions correlate with syntactic functions. In other words, in Mansi, information structure is primarily expressed by variation between different syntactic structures (active vs. passive inflection, indirective vs. secundative alignment, etc.), not by variation between word-order patterns. One of the aims of this study is to discover how information structure and constituent order interact with each other in Mansi.

Mansi word order is traditionally described in terms of syntactic functions. Mansi is regarded a language with a basic subject-object-verb (SOV) word order (see e.g. Kálmán 1989; Rombaneeva 1979; Riese 2001). Constituent order has been touched on and discussed by some scholars in the literature. Rombandeeva gives a description of Northern Mansi word order in her book on syntax, written in Russian (1979) and translated into German (1984). Rombandeeva can be regarded as the only native Mansi researcher and her contribution to Mansi linguistics is noteworthy.

Rombandeeva (1984:58-60) mentions seven rules concerning the placement of syntactic functions: 1) the subject and its modifiers always precede

1. In this study, the phenomenon of information structure is used as a subcategory of pragmatics. Both terms are used and often they refer to the same features or functions. 
the predicate, 2) the predicate is always in the sentence-final position, 3 ) the expression of time precedes the subject and is placed in the sentence-initial position, 4) the expression of location is immediately before the predicate, or in the sentence-initial position, 5) adverbials of manner, goal or reason precede the predicate, often also preceding the element they belong to, 6) the direct object is usually between the subject and the predicate, and 7) attributives always immediately precede the word they belong to. She also presents a description of placement of infinitives, question words, auxiliaries, causative verbs, conjunctions and particles (Rombandeeva 1984: 62-75). Further, she discusses the phenomenon of "logical emphasis", which is parallel to the phenomenon of information structure in the modern literature: she mentions that logical emphasis can also result in changes in word order (Rombandeeva 1984: 75-77). Rombandeeva's analysis is quite comprehensive, and one of my aims is to estimate its effectiveness by means of modern linguistics and with comprehensive corpus data.

After Rombandeeva, Mansi word order has been discussed on a narrower level by e.g. Riese (2001), Keresztes (1998), Kálmán (1989), Skribnik (2001), Bíró (2015), and Kulonen (2007). None of these authors gives a comprehensive description. Some mention the pragmatic perspective, but still the issue is not discussed thoroughly. The above-mentioned studies concern several different dialects and the differences between these dialects are relatively large, so features of one dialect cannot automatically be applied to other dialects. Riese (2001: 62-63) mentions that SOV is the basic word order, but he stresses that other orders are possible, if any constituent part bears a particular emphasis position. Kulonen (2007: 191-192) discusses Eastern Mansi, mentioning the basic SOV word order, the constituent order of verbless clauses, and the placement of modifiers and genitives. Skribnik (2001: 223), Keresztes (1998: 420) and Kálmán (1989: 63) all mention that the basic word order is SOV, but without any further elaboration.

Bíró (2015), referring to Riese (2001), notes that in Southern Mansi the basic word order can be changed to SVO due to pragmatic circumstances. Bíró also states that in Northern Mansi, the emphasized (i.e. the most focal) argument occupies the pre-verbal position, while the topic always occupies the sentence-initial position. Further, she presents the word order of indirect and secundative ${ }^{2}$ three-participant constructions (see e.g.

2. The secundative construction is also known as Secondary Object Construction (see Heine \& König 2010; Malchukov et al. 2010). 
Haspelmath 2015) both in active and passive in Northern and Southern Mansi, and comes to the conclusion that there is a pragmatic motivation behind the word-order variation between the different three-participant constructions. The most topical argument appears before the focal one, and the most focal argument is placed immediately before the predicate (Bíró 2015: 55). Consequently, instead of the most frequent order, RTV (where $\mathrm{R}$ = recipient; $\mathrm{T}$ = theme; $\mathrm{V}=$ verb), the rarer order, $\mathrm{TRV}$, is used only in indirect structures with objective conjugation. This variation is due to pragmatic reasons. (See Bíró 2015: 53.)

All of these comments are supported by my data, but none of them describes the situation thoroughly. This study fills in the gap between the partial studies mentioned above and offers a full description of Northern Mansi word order, including the variation within it. This article discusses Northern Mansi constituent order from two perspectives: 1) bringing a pragmatic level into the discussion, 2) comparing the author's contemporary data with that of other scholars - mainly Rombandeeva's (1979) observations - and elaborating them with new results and views. Thus, this is an attempt to develop a template approach to both the syntactic and the pragmatic level, and possible dependencies between them. ${ }^{3}$ The aim of this study is to observe how stable Northern Mansi constituent order is, and what factors the possible variation is based on. My key questions are:

1. What kind of constituent-order variation caused by information structure exists in Northern Mansi?

2. Is the same model applicable to all syntactic structures? Are there differences between active and passive, Indirect Object Construction and the Secondary Object Construction, questions or imperatives and declarative sentences?

3. How does my data support Rombandeeva's observations? How can my analysis supplement or develop Rombandeeva's results?

Before proceeding, some terminology needs to be defined. My emphasis is on how the main syntactic constituents are organized inside the clause. One constituent may include several words; there may be modifiers or non-finite

3. At this point, I would like to express my gratitude to docent Maria Vilkuna for all consultation and discussions on this study. Her advice have been more than helpful during this process. 
verb forms connected to the main word. If we go further and consider the order of the components of the constituent, we talk about word order. Here, however, the emphasis is on constituents. I use the term "word order" only when referring to studies discussing word order itself or using this term.

In this context, it is also important to distinguish between syntactic functions, semantic roles and pragmatic status. One part of this study is how these levels of language correlate with each other. Syntactic functions (constituents) are referred to with well-established syntactic terms: subject (S), direct object (DO), indirect object (IO), temporal adverbial (Temp), locational adverbial (Loc), manner adverbial (Man) and agent adverbial (AgA). The category of indirect objects include two different types: the lative-marked recipient $\left(\mathrm{IO}_{\mathrm{LAT}}\right)$ and the instrumental-marked semantic patient $\left(\mathrm{IO}_{\mathrm{INSTR}}\right)$. The category of adverbials is simplified to include four main categories: time, location, manner and agency. Most of the adverbials found in the data are classified among these four main types. In addition, there is a class of other adverbials for some less frequent cases like conditional or reason adverbials. Further, the phenomenon of scene-setting adverbials (ScSA) is applied: this is not an independent syntactic category, but a specific category including several types of adverbials and carrying a particular pragmatic status. A scene-setting adverbial is a temporal or locational adverb which is placed at sentence-initial position and sets a spatial or temporal framework within which the main predication holds (see e.g. Chafe 1976: 50).

Respectively, the semantic roles are named agent, patient, theme, recipient, locative, goal and source. For pragmatic status, I use the terms primary topic, secondary topic and focus. The primary topic is the most topical element in the utterance, it is the constituent the whole sentence is about. The secondary topic is also topical but less salient. Focus is new, unpredictable or contrastive information brought to the discussion. (See e.g. Lambrecht 1994: 118, 207; Dalrymple \& Nikolaeva 2011; Virtanen 2014.) In a broader sense, when analysing corpus data, we can also talk about narrative topic, which is the most topical element in the whole text or spoken entity.

Further, typological features typical for Mansi have implications for terminology. In Mansi, both active and passive conjugation paradigms correlate with the syntactic subject of the clause (see Section 2.1). I distinguish the subjects of active and passive clauses by marking them SA (Subject, Active) and SP (Subject, Passive). I only pay attention to the opposition between SA and SP where it causes differences in the constituent order. Otherwise, active and passive clauses are treated equally. Secondly, we cannot ignore 
the fact that Mansi is a language with a high frequency of zero anaphora: a subject or a DO is often not expressed explicitly with a nominal constituent, if it is a topical argument and referred to with a conjugation suffix.

In the following, I approach Mansi constituent order by describing how and why the placement of individual syntactic functions varies between two or more templatic slots. This is discussed at the clausal level, because each clause normally has its own verb and represents an independent meaningful unit. According to my data, this model works with both active and passive clauses. The structure of this article is as follows: In Section 2 I present the most remarkable typological features of Mansi and then, in Section 3, some general facts about word-order typology. Section 4 is devoted to my research data and the implementation of my analysis, and the detailed results of my data are given in Section 5. The main conclusions are gathered in Section 6.

\section{Information structure in Mansi}

In this section I briefly discuss some relevant information-structure features of Mansi. Information structure is primarily expressed by variation between different syntactic structures (see e.g. Skribnik 2001; Virtanen 2015). The data presented in this section is not to describe Mansi constituent order, but to demonstrate the pragmatic variation between different syntactic choices. To understand the details of Mansi constituent order, one has to be aware of the features presented in this section.

First of all, variation between the active and the passive voice is due to a correlation between syntactic and pragmatic functions: the higher in the pragmatic hierarchy $\left(\mathrm{PT}>\mathrm{ST}>\mathrm{F}^{4}\right)$ an argument is, the higher the syntactic function (Subject $>\mathrm{DO}>$ Oblique) it occupies (see e.g. Virtanen 2015). The pragmatic status of a single argument is defined by examining the following features: 1) the argument's possible inherent topicality $\left.{ }^{5}, 2\right)$ the argument's appearance in the same text, in the same paragraph, in previous sentences and in the immediately preceding sentence, and 3) any contextual factors affecting the status.

4. $\mathrm{PT}=$ Primary Topic, ST = Secondary Topic, $\mathrm{F}=$ Focus; see Section 1.

5. Inherent topicality is a property that indicates a concept being automatically more easily accessed than others, regardless of the discourse context (see e.g. Taylor 1996: 219-220). For example the 1st and 2nd person referents are very inherently topical, because they are always already accessible in the discourse situation. 
If any semantic role other than the agent (i.e. patient, recipient, sometimes even locative ${ }^{6}$ ) is promoted to the subject (i.e. it is the most topical syntactic argument), the passive is used. Variation between active and passive is demonstrated in examples (1-4). In examples (1) and (2) the semantic agent of the sentence is the primary topic, so an active structure is chosen to place the agent in the syntactic function of subject. In (3) and (4), a passive structure is chosen, because the primary topic is not the semantic agent. In example (1) the chosen sentence, and indeed the whole text, is about an old man. He is referred to by a third-person singular pronoun, which represents the pragmatic primary topic. Because it represents the semantic agent as well, an active sentence is used:

\begin{tabular}{|c|c|c|c|c|}
\hline Ха̄льӯс & район & Саранпа̄выл-т & сам-ын & пат-ыс. \\
\hline Taw Xāl'ūs & & Saranpāwal-t & sam-ən & \\
\hline 3SG Beryozovo & district & Saranpaul-LOC & eye-LAT & start-PST.3SG \\
\hline
\end{tabular}

The sentence in example (2) is from another article about Ekur, another old man, whose life story has been discussed for several preceding sentences. Ekur represents the primary topic of the sentence; the sentence gives more information about him. The primary topic of the sentence is also the semantic agent: when it occupies the syntactic function of subject, it triggers an active sentence structure:

$\begin{array}{lll}\text { Екур } & \text { кӯщаи-г } & \text { хульт-ыс. } \\ \text { Ekur } & k \bar{u} s ́ a i-\gamma & \text { xul't-əs. } \\ \text { Ekur } & \text { head.person-TRANSL } & \text { stay-PST.3SG } \\ \text { 'Ekur stayed as a head of the household.' (LS 9/2014: 13) }\end{array}$

Example (3) is about the President of the Russian Federation being taken to a museum. The article is about him, and he is also the primary topic of this sentence. In this case, however, someone else is taking him to the museum. The third-person singular pronoun represents the semantic patient, but at the same time it is the primary topic of the sentence. A passive sentence structure is chosen, and the verb is inflected in the past tense and third-person singular:

6. Also the semantic role of locative can in some rare cases occupy the syntactic function of subject (e.g. Kulonen 1989: 152). 


\section{Constituent order in Northern Mansi}

(3)

$\begin{array}{lll}\text { Тав та̄pa } & \text { музей-н } & \text { тот-ве-с. } \\ \text { Taw tāra } & \text { muzej-n } & \text { tot-we-s. } \\ \text { 3SG tradition } & \text { museum-LAT } & \text { take-PASs-PST.3SG } \\ \text { 'He was taken to the Museum of Traditions.' (LS 21/2018: 2) }\end{array}$

Example (4) is a passive clause and includes a semantic agent, which has the syntactic function of agent adverbial and is marked with the lative case. The article in question discusses patients, who represent the primary topic of the sentence. The new information provided is that in certain cases doctors send them to their own hospital. The third-person plural pronoun (i.e. the patients) is the semantic patient of the sentence and occupies the syntactic function of subject. Therefore, the verb is inflected in the passive third-person plural:

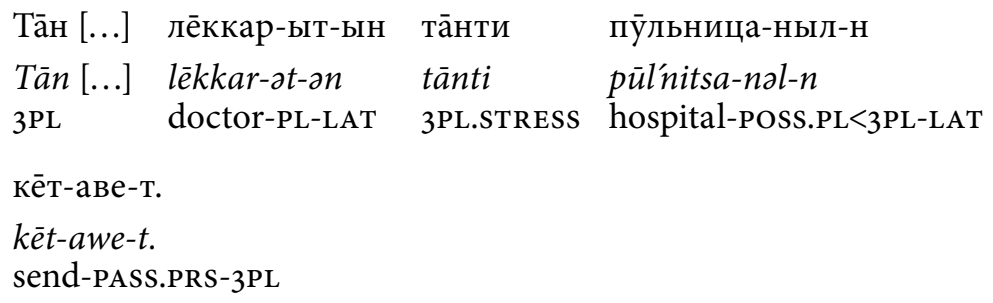

In active transitive structures, information structure is also reflected in DOA/DOM. Skribnik (2001) has discussed this concerning Northern Mansi, as has Virtanen (2014) concerning Eastern Mansi. Mansi marks a topical DO by indexing on the verb, but not focal indexing. In other words, there are two verb-inflection paradigms in Mansi. The objective conjugation is the primary technique for indexing a topical DO, it is used when the verb is accompanied by a topical DO (see Virtanen 2013; 2014). An objective-conjugation ending indicates the person and number of the subject, as well as the number of the DO. The subjective conjugation is used when there is no DO (intransitive action, or transitive action without a specified object), or it is accompanied by a non-topical (focal) DO. Examples of these variations can be found here, for instance, in examples (5), (9), (27), (28), (29) and (39) for the objective conjugation and (1), (2), (6), (7) and many others for the subjective conjugation.

A good example is number (5) below, where the DO turns from focal to topical. When the book or report is first mentioned with its author, 
the verb is in the subjective conjugation ( $х$ aнсыс 'wrote'), because of the focality of the DO. Right after that, the book is topicalized, and in the next clause it appears as a topical DO only referred to with an objectiveconjugation verb ending ( topic of the latter clause, while the subject remains the primary topic of the whole sentence.

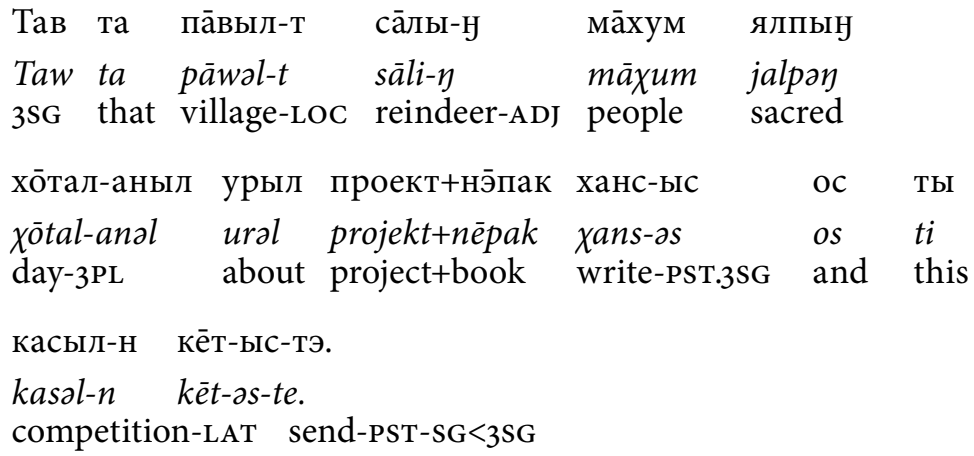

'She wrote a project report about the sacred day of the reindeer keepers in the village, and sent it to a competition.' (LS 23/2019: 2)

Further, the most topical subjects and DOs are not expressed explicitly at all but only referred to with a verb ending. Examples (6) and (7) are equal main clauses of the same sentence. Both of them lack an overt subject, which is only referred to with a past tense ending, a zero ending referring to the singular third-person. The subject referent is a reindeer, but due to its high topicality and mentions in the immediately preceding sentences, the noun argument is not repeated here:

(6) Тӯр ва̄та хосыт ёмант-ас [...]

Tūr wāta xosat jōmant-as [...]

lake coast along saunter-PST.3SG

'[The reindeer] sauntered along the lakeside [...]' (LS 15/2017: 15)

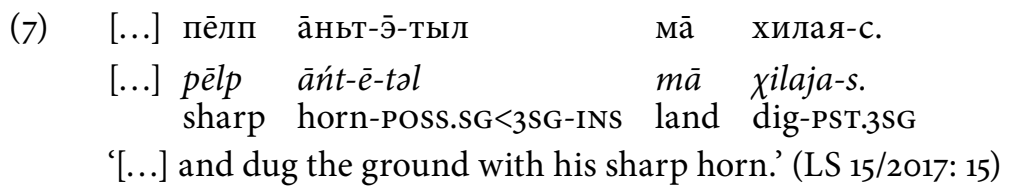


In the same way, in (8) there is no overt third-person plural subject in the passive clause. The text is about patients and how they are taken care of and informed about illnesses; the phenomenon of patients of the hospital is very accessible in this context. For this reason, a highly topical subject can be recognized by the context, and it is referred to with a normal verb ending.

\begin{tabular}{|c|c|c|}
\hline Ма̄нь & нэ̄пак+ло̄мт-ыт-ыл & май-вё-с-ыт [...] \\
\hline $\begin{array}{l}\text { Māń } \\
\text { small }\end{array}$ & $\begin{array}{l}n \bar{e} p a k+l \bar{m} m t-\partial t-\partial l \\
\text { book+piece-PL-INS }\end{array}$ & $\begin{array}{l}m a j-w \bar{e}-s-\partial t \quad[\ldots] \\
\text { give-PASs-PST.3PL }\end{array}$ \\
\hline
\end{tabular}

Besides the variation between active and passive described above, there is pragmatic variation between ditransitive structures (see 9-11). Northern Mansi ditransitive constructions have recently been examined by Bíró and Sípöcz (2017) from the typological point of view. Referring to the terminology of Malchukov et al. (2010), they state that the Northern Mansi ditransitive constructions are the Secondary Object Construction (SOC) (or Secundative Alignment) and the Indirect Object Construction (IOC) (or Indirective alignment) (Bíró \& Sípőcz 2017: 44-45). Also in ditransitive clauses, both active and passive, the most topical element occupies the syntactic function of subject and is the one the verb correlates with.

Example (9) illustrates the active Secondary Object Construction, where the semantic recipient occupies the syntactic function of DO, while the semantic theme appears as an instrumental-marked IO. A structure like this is used when the semantic theme is the pragmatic focus of the sentence, and the recipient is the secondary topic. Example (9) is from a news article about administration workers. Local leaders are awarding some of them for their good work. These leaders have been mentioned previously, so the semantic agent (third-person plural pronoun) is the primary topic and occupies the syntactic function of subject. The semantic recipients have been mentioned and are textually topical (their exact number is mentioned for the first time, whereas previously an approximation was given). So, the recipient is the pragmatic secondary topic: it appears as a syntactic DO and is accompanied by the objective conjugation. The new information in the sentence is the award of Certificates of Merit: as a focal argument the semantic Theme (Certificate of Merit) occupies the syntactic functions of IO, and it is inflected in the instrumental case. 


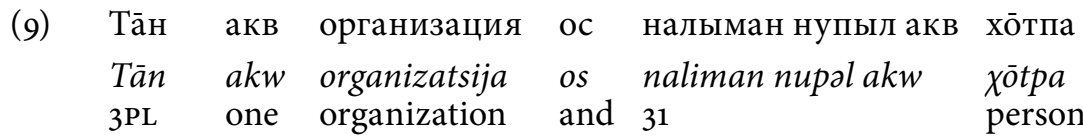

Почётный грамота нам-па нэ̄пак-ыл ми-с-аныл.

Potšotnijgramota nam-pa nēpak-al mi-s-anal.

certificate.of.merit name-PTCP document-INS give-PST-SG $<3$ PL

'They gave [documents called] Certificates of Merit for [the aforementioned] one organization and 31 persons.' (LS 14/2018: 2)

Examples (10) and (11) are both from a newspaper article about the Russian president's visit to Khanty-Mansiysk: (10) is the title of the article. The most topical element of the clause is the president. The new information (focus) in the title line is that he was given a traditional Mansi belt. For this reason, the passive Secondary Object Construction is used: the semantic recipient occupies the syntactic function of subject, and the semantic theme is marked with the instrumental case (as in 6). The semantic agent, which is focal as well, is marked with the lative case.

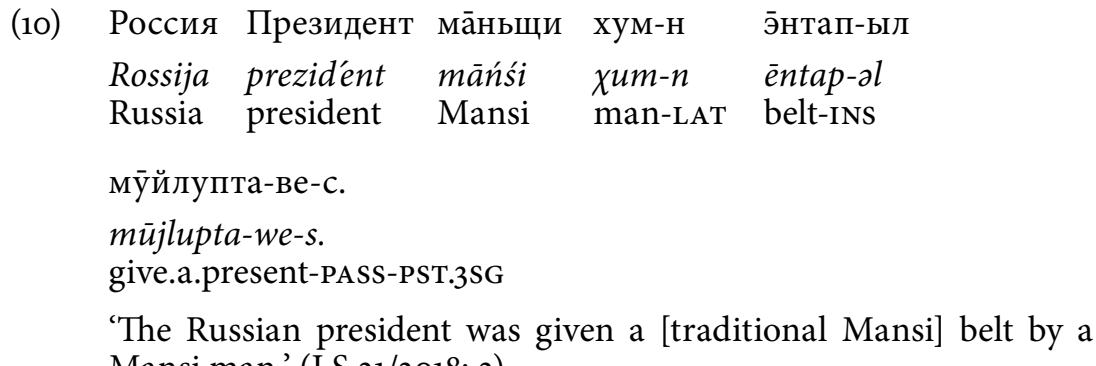
Mansi man.' (LS 21/2018: 2)

The active sentence in example (11) illustrates the Indirect Object Construction: it is from the same article as example (10) and discusses the exact same action, but from a wholly different perspective. In (11), the semantic agent appears as the subject of the sentence: from the context we know that the man, called Aleksandr, is one of the performers in the visit program, as he has been mentioned along with two other persons in preceding sentences. Consequently, the semantic agent is the pragmatic primary topic and appears as the syntactic subject. An active sentence structure is chosen. The belt, the semantic theme, is focal, so it is accompanied by the subjective conjugation. The semantic recipient, the president, is marked with the lative case. 


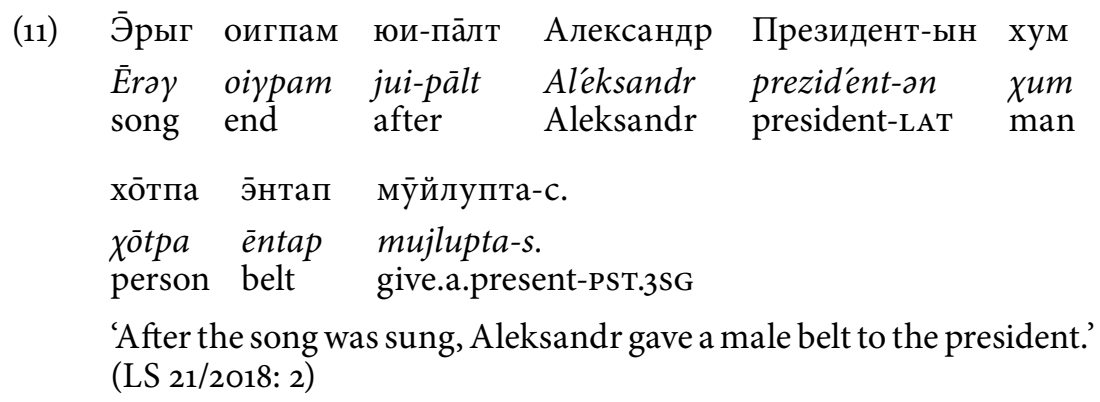

To sum up, Table 1 gathers together correlations between different sentence structures, semantic roles and syntactic functions (for more details, see Virtanen 2015: 53-58). On the horizontal bar we can see the active and passive 1-participant (intransitive), 2-participant (monotransitive) and 3-participant (ditransitive) structures. The vertical bar is for the semantic functions, and the chosen syntactic functions are marked as matches between the sentence structures and the semantic functions. These are not absolute correlations, but on a large scale, these are reliable prototype situations.

Table 1: Summary of correlation between semantic and syntactic functions in different syntactic structures

\begin{tabular}{|c|c|c|c|c|c|c|c|c|}
\hline & $\begin{array}{l}\text { Active } \\
1-\mathrm{P}\end{array}$ & $\begin{array}{l}\text { Passive } \\
1-P\end{array}$ & $\begin{array}{l}\text { Active } \\
2-\mathrm{P}\end{array}$ & $\begin{array}{l}\text { Passive } \\
2-\mathrm{P}\end{array}$ & $\begin{array}{l}\text { Active } \\
3-\mathrm{P} \\
\text { Sec. }\end{array}$ & $\begin{array}{l}\text { Active } \\
3-\mathrm{P} \\
\text { Indir. }\end{array}$ & $\begin{array}{l}\text { Passive } \\
\text { 3-P } \\
\text { Indir. }\end{array}$ & $\begin{array}{l}\text { Passive } \\
\text { 3-P } \\
\text { Sec. }\end{array}$ \\
\hline Agent & Subject & - & Subject & $\begin{array}{l}\text { Oblique } \\
\text { (LAT) }\end{array}$ & Subject & Subject & $\begin{array}{l}\text { Oblique } \\
\text { (LAT) }\end{array}$ & $\begin{array}{l}\text { Oblique } \\
\text { (LAT) }\end{array}$ \\
\hline Theme & & Subject & DO & Subject & $\begin{array}{l}\text { IO } \\
\text { (INSTR) }\end{array}$ & DO & Subject & $\begin{array}{l}\text { IO } \\
\text { (INSTR) }\end{array}$ \\
\hline $\begin{array}{l}\text { Recip- } \\
\text { ient }\end{array}$ & & - & - & - & $\mathrm{DO}$ & $\begin{array}{l}\mathrm{IO} \\
(\mathrm{LAT})\end{array}$ & $\begin{array}{l}\mathrm{IO} \\
\text { (LAT) }\end{array}$ & Subject \\
\hline
\end{tabular}

As the table above shows, each semantic role is realized as multiple syntactic functions. How does this variation influence the linear order of syntactic functions in an utterance? The variation between different syntactic structures described in examples (1-11) above is dependent on the correlation between syntactic and pragmatic functions, while the constituent order is primarily in connection with syntactic and pragmatic functions of individual arguments. As described in the following sections, the constituent order is not dependent on the chosen syntactic structure: the same linear 
order can be applied to any structure (e.g. active, passive, 2-participant and 3-participant). In Section 5, I demonstrate the pragmatic constituent order variation I found, and how it works in different syntactic solutions.

\section{Word order and constituent order as a typological question}

In this section, I briefly present some general features and tendencies of word-order typology, and then proceed to the pragmatic approaches (Section 3.1). Finally, I discuss the phenomenon of the syntactic template as a device for describing constituent-order variation (Section 3.2).

\section{I. Perspectives on word-order typology}

Word order can be examined from several perspectives, which are situation-dependent. In his word-order handbook, Song (2012: 3-4) sees four approaches as relevant to linguistics today: linguistic typology, generative grammar, optimality theory and performance-based theories. From the point of view of this study, optimality theory and performance-based theories are the most relevant. It is also worth mentioning linguistic typology, which was used also in the seminal typological analysis by Greenberg (1963). Greenberg's approach, the first attempt ever to create a comprehensive word-order typology, concentrates on basic word order, i.e. the order of a stylistically neutral, independent, indicative clause with full nounphrase participants; it is a prototypical transitive clause (Siewierska 1988: 8). Basic word order is normally approached by examining the division of the syntactic core arguments Subject (S), Direct Object (O) and Verb (V). The frequency hierarchy of the six basic word-order patterns is SOV > SVO $>$ VSO $>$ VOS $>$ OVS $>$ OSV (Song 2012: 25).

Optimality theory has been derived from generative grammar and, as the name implies, aims at achieving optimal output selection in word order (see e.g. Costa 1997; 1998; 2001; Zepter 2003). In the terms of the theory, an input can be realized as different outputs, and violable constraints affect the decision between possible outputs. The aim is to find the optimal satisfaction within conflicting constraints. There are no language-specific restrictions on the input, only on the output. Similarly to linguistic typology, optimality theory is very focused on basic word order.

Within the performance-based approach, Song mentions the Principle of Early Immediate Constituent Theory. In this view, different word 
orders reflect the way languages respond to the demands of rapid and efficient processing in real time (Hawkins 1994: 57; Song 2012: 237). Briefly, language use is social interaction, and it should be approached from the perspective of how the hearer is receiving it. The hearer's processing is maximized when the immediate constituents of a given syntactic domain are recognized as rapidly and as early as possible (Song 2012: 259). Song criticizes Hawkins for focusing on processing rather than producing language (Song 2012: 259-260). Considering both opinions, Hawkins's theory has something in common with information-based theories like the one used here; information-structure research deals with the question of what the hearer is expected to know and understand.

While Song intends to be comprehensive, he wholly ignores information-based theories, only briefly referring to some approaches. He justifies his choice by stating that information-based theories vary widely, that referring to Hawkins (1994) - they do not play a remarkable role in wordorder-related research, and they fail to address the issue of grammaticalized word orders and correlations (Song 2012: 6-7). Contesting these views, the pragmatic or information structural level is essential to the analysis in this study. The Mansi basic word order has been proven to be SOV (see Section 1). My analysis extends to variation beyond the basic word order. Word order flexibility is possible, as basic word order patterns in an individual language vary considerably (Siewierska 1988: 10-11). It is important to note that in the research material used here, the different placement possibilities of the other arguments (besides $\mathrm{S}, \mathrm{O}$ and $\mathrm{V}$ ) may also vary due to pragmatics.

Siewierska examines word-order variation using linearization hierarchies. Referring to Allan (1987), she classifies them into three groups: formal hierarchies (e.g. length, structural simplicity or complexity), dominance hierarchies (e.g. personal hierarchies, semantic roles) and familiarity hierarchies (Siewierska 1988: 29-103). The familiarity hierarchies include the more familiar > less familiar hierarchy, the topic > comment hierarchy and the given $>$ new hierarchy (Siewierska 1988: 61-75). She also mentions definiteness and referentiality hierarchies. In the broadest sense, all of the above are connected to information structure. Giving examples from various languages, Siewierska demonstrates how the word order of a single language can be affected by familiarity, topicality and the givenness or definiteness of the referents. Whether any familiarity hierarchy affects the word order or not is language-dependent: this is not possible in languages with a fixed word order. Downing (1995: 15-16) discusses the question of 
topicality and word order: using the traditional terms theme and rheme she grounds the need of theme-initial utterances with the natural need to present the thematic, known information first, and to share the most unpredictable information at clause-final position. As I show in Sections 5 and 6, my Mansi data supports Downing's statement.

The difference between languages with fixed and pragmatically conditioned word order can be described using the opposition of configurational vs. non-configurational languages (see e.g. Hale 1983; Baker 2003). In configurational languages, syntactic functions occupy fixed places within the sentence structure, while in non-configurational languages the placement of a single constituent is dependent on other factors. As my data show, Mansi is neither a purely configurational nor a non-configurational language: some syntactic functions have fixed positions inside the syntax while others are placed according to their pragmatic functions. Van der Wal (2009) has come up with a similar conception: languages are not purely configurational or non-configurational, but rather they lie on a continuum of different features. Van der Wal (2009: 134) also questions the whole phenomenon of non-configurational language:

[...] the term 'non-configurational' does not seem appropriate to refer to languages. There are striking differences between languages in terms of word order and constructions, so the question is: what determines the configuration of sentences in a language? For the 'configurational' languages, the most influential factor is the syntactic functions and argument relations.

How should we refer to a language which is not a configurational one? É. Kiss (1995) describes Hungarian - a close relative to Mansi - with the term discourse configurational language: in a discourse configurational language pragmatic functions occupy fixed places within the syntax. Similarly Vilkuna $(1989 ; 1995)$ has described Finnish word order as a discourse conditioned system. She defines the three main parts of sentence structure as the K, T and V fields (Vilkuna 1989: 37-40): $\mathrm{T}$ is for the function of a constituent that immediately precedes the finite verb in a textually neutral sentence, $\mathrm{K}$ is for the function of a constituent that precedes $\mathrm{T}$, and the $\mathrm{V}$ field is the part of sentence that follows T. Despite the slightly complicated definitions, in practice $\mathrm{K}, \mathrm{T}$ and $\mathrm{V}$ refer to pragmatic functions that occupy fixed places within the linear order: they function as pragmatic domains and are not directly connected to syntactic functions. 
É. Kiss (1995: 6) defines two properties of discourse configurational language: 1) the discourse-semantic function topic is expressed through a particular structural relation; 2) the discourse-semantic function focus is expressed through a particular structural relation. In Mansi, the first property means that the syntactic function of subject - with some natural exceptions - correlates with the most topical element of the sentence: variation between the active and the passive voice is due to correlation between syntactic functions and pragmatic status (see examples in Section 2). The second property is realized by placing focal elements in syntactic noncore functions, and as a natural consequence of the previous statement, often marking them with oblique cases. (See e.g. Skribnik 2001; Virtanen 2016.) However, these conditions are not fully met in Mansi, for as Skribnik (2004) describes, also subject foci are possible in particular conditions.

At this point it is worth mentioning that in connection with (di)transitive structures, the variation between constituent order has also been examined from the point of view of valency. It has been proven that, for example, in German the obligatory adverbials (in terms of the valency) follow the non-obligatory ones in the surface word order (see Flämig 1991). Valency factor is excluded from this current study, because the following template analysis proves very clearly that the adverbials are placed according to their functions (time, place and manner). Combining valency with this analysis would likely not bring any valuable further results. This does naturally not exclude the possibility of examining the effects of valency in further studies.

\subsection{Syntactic template as a device for describing constituent-order variation}

Observing Mansi data easily raises the question whether the language can be defined as purely configurational or non-configurational at all, since it demonstrates features of both. The closest definition would be discourse configurational, but this still needs elaboration. In the following sections I will demonstrate how Northern Mansi constituent order is dependent, on the one hand, on syntactic functions, and on the other, on the order of pragmatic status. This complex two-level system is described by template analysis. A template approach can be used to observe the variation in constituent order from several perspectives: this way a partly configurational or discourse configurational language can be described on both the syntactic and pragmatic levels simultaneously. This shows that what we 
call variation above, actually only varies in terms of syntactic functions, because from the interdimensional point of view, constituent order is very consistent. My main aim here is to describe the factors affecting Mansi constituent order as fully as possible.

The term "template" is not easy to define, because it includes various kinds of analysis of different levels of language structure, and it is not meant to refer to a strictly delimited device. Good (2016: 7) defines a template as follows: "An analytical device used to characterize the linear realization of a linguistic constituent whose linear stipulations are unexpected from the point of view of a given linguist's approach to linguistic analysis." However, Good (2016: 22-23) points out that the citation above is a descriptive definition, not a prescriptive one. Further, Good amplifies his definition by specifying that when greater terminological precision is needed, the term desmeme should be applied to emphasize merely linear stipulation, and to avoid the problematic phenomenon of unexpectedness (Good 2016: 23). In other words, template analysis can be adapted to situations with expected stipulations as well.

A template can be used for describing morphological, morphophonological or - as is done here - syntactic linearizations. Morphophonological and morphosyntactic templates have a prominent place in the literature (Good 2016: 66), but that does not exclude the use of syntactic templates either. According to Good (2016: 17-18), templates have been successfully applied to German syntax (Höhle 1986; Kathol 1995; 2000; van Riemsdijk 2002) and Dutch syntax (Shannon 2000). Interestingly, the work of Vilkuna (1989; see Section 3.1) on Finnish syntax can also be regarded as a template analysis, as the three fields she applies to constituent order can be understood in the same way as the slots in my analysis (see Section 5). Mansi and Finnish are distantly related languages, and while they are very different, they share some common features.

The vast diversity of environments where templates are applied are well reflected in the unsettledness of the terminology and practices used. The aim of a template analysis is to identify and define the factors that influence the linear order of components, and in the following, these linear positions are called slots. There is no single correct way of doing template analyses. As Good humorously expresses it, templates are "a twice incoherent class of phenomena" (Good 2016: 22) or a "wastebasket" (Good 2016: 27). Though many kinds of approaches are taken, a common feature is that the final result is a linear representation of the components involved. 


\section{Constituent order in Northern Mansi}

Good (2016: 40-103) makes an effort to provide a settled template terminology, which he calls a description language for templates. He describes in detail how the elements and features involved in the analysis should be named, and how the terminology varies. He starts by defining basic phenomena like stricture, foundation, desmeme and component, and describing their features. Every template analysis practically includes these four elements, even if they are not named so. According to Good's (2016: 53-54) terminology, component is an immediate subconstituent of a given templatic construction: the analysis normally discusses the occupancy of the components. In this study, components are syntactic (phrasal) constituents that occupy numbered slots inside the template. Stricture is a feature that classifies the nature of the linearization specifications in a given template: it is either the length or the order of the components (Good 2016: 66). In this study, the stricture is simply order: the main question concerns the linear order of the syntactic constituents. Foundation is a feature describing how components of a template are organized into an overall templatic form; the foundation can be either span or arch type. A span foundation includes left-support components and right-support components, and the remaining components (Restkomponenten) are placed between them. An arch foundation is built around a keystone, which is the topmost component at the centre (head) of the template. The components directly adjacent to the keystone are called voussoirs, and they are either left-support or right-support - depending on which side of the keystone they are placed. (See Good 2016: 75-77.)

As can be seen in Section 5, this current template analysis represents the span model with a right-support verb and a left-support primary topic. In other words, both syntactic and pragmatic functions are involved simultaneously. Finally, desmeme is used as a synonym for template: it refers to the whole linear pattern analysed (Good 2016: 65). The desmeme is here represented by a clause. Before proceeding, it is worth noting that this template analysis does not exactly adhere to any kind of "Good's model", although it can be described in the framework of Good's terminology. For the needs of this study, in the light of recent research and the nature of my data, the template analysis had to be applied to the pragmatic level. This kind of template analysis enables accurate and interdimensional observation of the linear order of constituents when the order is affected by both syntactic and pragmatic factors. This model results in partly very similar descriptions as Rizzi (1997) or É. Kiss (1995). Rizzi and É. Kiss, however, 
focus on realization of the main pragmatic functions, while my template analysis gives an interdimensional description of the effects of both pragmatic and syntactic factors. Placement possibilities of individual functions are discussed as a part of a larger entity. The details of implementation of my template analysis are presented in Section 5.

\section{Research data and implementation of the analysis}

In this section, I will first briefly present the source and content of my research data, and then describe the classification of the data and implementation of data classification and the analysis.

\section{I. Research data}

My data are gathered from Лȳuмā сэ̄punoc [Lūimā Sēripos], the only upto-date Mansi newspaper, published twice a month in Khanty-Mansiysk. An average issue contains 15-20 pages. Although the data is from one single source, the genres published within it vary, e.g. standard news articles, interviews, letters from readers and folklore texts. Altogether 12 articles or other texts are included from the 2014, 2017 and 2018 volumes of the newspaper, a total of 676 entries. The 12 articles were chosen so that different genres, variable topics and different authors are represented, but also so that the length of an individual article is between 20 and 150 clausal entries.

This source was chosen mainly due to its contemporary nature and sufficient variety. The sources for written Mansi are limited, because the language is used only in restricted circumstances. The easiest way to include folklore texts was to gather them from the same source as all other data, because the same Cyrillic orthography is applied. The data naturally includes various sentence types, such as declaratives, questions and imperatives, which vary according to the genre of the text. When something in the analysis is connected to the sentence type, this is clearly stated. Most often the same model can be applied to any sentence type, as the next section will show. 


\subsection{Implementation of the analysis}

My template analysis was implemented in several phases, where the results of one phase led to decisions concerning the next one. The data have been first divided into clauses, and one clause provides one entry. The final result was a 9+1 slot model, which I found suitable for describing the variation of syntactic order. This analysis was not implemented in pre-planned steps, rather finishing one step always led to decisions concerning the next one. Afterwards, I named the phases as follows:

1. Providing desmemes (chains of constituents) out of clauses.

2. Creating a table with desmemes on horizontal lines.

3. Adjusting the components (constituents) and the slots (vertical columns).

4. Deciding on the number of slots and naming them. Adding a pragmatic level to the analysis.

5. Turning the template to a vertical position.

6. Analysing variation in placement of single syntactic functions and deepening the pragmatic level of the analysis.

In the fifth phase, the template was turned to a vertical position, as presented in Table 2. Beside the syntactic analysis presented above, also a preliminary pragmatic analysis was implemented: the individual referents were analysed according to their appearance in the whole text, in the same paragraph, in previous sentences and in the immediately previous sentence. In this way they were defined as primary topics, secondary topics, scene-setters and foci or pragmatically neutral arguments. Also their possible inherent topicality was examined. This analysis resulted in preliminary remarks on how the topicality or focality of an individual argument influences its placement inside the linear order. Still, the real analysis was finished in the sixth phase, when the results and conclusions were combined in the form of a pragmatic template (see Table 4 in Section 6).

The preliminary template (see Table 2 ) has $9+1$ slots and includes alternative slots: for example, subject varies for pragmatic reasons between two slots ( 1 and 7 ), and both are marked in the table. Already in this phase, some rearrangement was carried out to combine the pragmatic analysis with the syntactic one. For example, focal DOs were moved from Slot 6 to Slot 8 , in case Slots 7 and 8 were not occupied yet. The first slot of this model is marked o, because it is occupied quite rarely and only by elements that do not affect the order of the other constituents. 
Table 2: Ten slots filled by syntactic or pragmatic functions. The template is refined in Section 6.

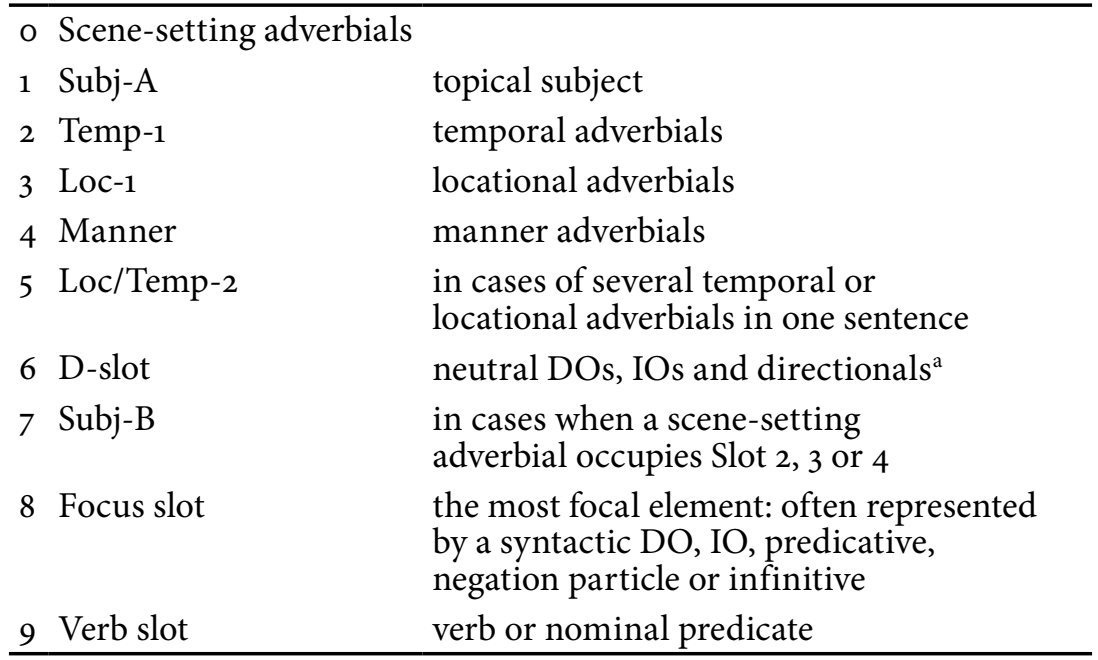

a. For the definition of directionals or directional adverbials, see Section 5.3.

Before proceeding, note that the template is refined in the sixth phase of the analysis (see Section 6). The interdimensional nature of the analysis makes the description complicated. Because of the pragmatic variation described in Section 2, one syntactic function often correlates with particular pragmatic functions. There are syntactic functions that always occupy the same linear positions, with minor exceptions, but also pragmatic functions that occupy a certain position independently of the syntactic functions they represent: mapping out these occupancies is one of the main aims of this article. There are very clear and visible constituent-order hierarchies between syntactic functions. Some functions occupy their own slots alone; some slots are shared by several functions. If there is a function missing from an individual sentence structure, the slot in question remains unoccupied.

In the following Section 5 , this approach is presented function by function, not in the numerical order of the slots but starting with the syntactic core arguments and their placement, and proceeding towards the less prominent constituents. Finally, an elaborated template model (Phase 6) is presented in Section 6. 


\section{Linear placement of syntactic functions in my data}

In this section, I present the core findings of my analysis is detail, taking into account both the syntactic and pragmatic level simultaneously. Subsection 5.1 is devoted to the clause-final placement of verbs. In Section 5.2, the placement of subject and its variation are discussed in detail. Indirect and direct objects are discussed in Section 5.3, and the adverbials of locations, time and manner in Section 5.4. Finally, the placement of agent adverbials, nominal predicates and infinitives is presented in Section 5.5, and some questions concerning interrogatives in Section 5.6.

In the following subsections, the data examples are preceded by a template description: above each original data sample, the syntactic functions are listed in the right linear order, accompanied by their slot numbers. For example, a manner adverbial in Slot 4 is labelled "Man:4", a predicate verb in Slot 9 is labelled "V:9", etc.

\section{I. On verb-finality}

According to Rombandeeva (1984: 58-60), the strongest or most stable feature of Northern Mansi word order is that the verb always occupies the absolute clause-final position. My data support Rombandeeva's statement: 624 examples out of 676 are verb-final. This means that $92 \%$ of the clauses are verb-final, but not all include a predicate verb; of those clauses which do include a predicate verb, $99 \%$ are verb-final. $99 \%$ of all clauses without a predicate verb include a nominal predicate placed at slot 9 (see Section 5.5). A verb can be only followed by a conjunction or - due to recent Russian influence - an infinitive.

Examples (12) and (13) are typical verb-final sentences that represent the strong majority in my data. Independently of the pragmatic context, the verb occupies the sentence-final position in both the active (12) and the passive (13).

Man:4-V:9

(12) Ка̄сын хо̄тпа э̄р-нэ тэ̄ла-т урыл потырт-ас.

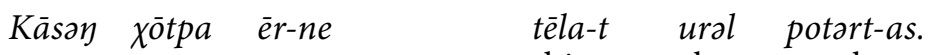

every person concern-PRS.PTCP thing-PL about speak-PST.3SG 'She talked about things that concern all of us.' (LS 1/2018: 6) 
SP:1-Adv:8-V:9

(13) Йильпи кол тай са̄в уेнтт-аве.

Jilpi kol taj sāw ūntt-awe.

new house PTCL many build-PASS.3SG

'A lot of new houses are being built.' (LS 1/2018: 5)

Example (14) illustrates another default situation. The predicate is followed by a conjunction but is still regarded as sentence-final. In Table 2 the corresponding slots are Slot 9, and a conjunction following it.

SA:1-V:9-Conj

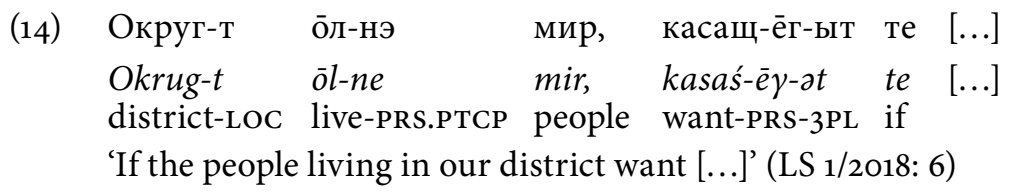

To sum up, the verb or a nominal predicate occupies the verb-final position and, in any clause type (for nominal predicates, see Section 5.5), it may only be followed by conjunctions or infinitives. Complex predicates are briefly discussed in Section 5.5. There are only minor exceptions to this rule in my data, and these exceptions are clearly due to Russian influence and not discussed here.

\subsection{Placement of the subject}

One of the most regular alternation types in my data is the variation in the placement of the subject in active and passive clauses (SA and SP) between two stable slots. Rombandeeva $(1979 ; 1984)$ mentions that the subject precedes the predicate, and my data support this statement with minor exceptions. ${ }^{7}$ In my analysis, I reserved two slots ( 1 and 7 ) for subjects. These two slots are symmetrically occupied by subjects - not simultaneously but in either one or the other. Slot 1 is called Subj-A, and Slot 7, Subj-B in my analysis. Analysing corpus data, however, is not so simple. For example, if we have a clause with only a subject and a verb, or with a subject, a DO

7. In some special cases the syntactic Subject is placed just after the Verb. These cases are not relevant from the point of view of this study, and they are not discussed here. 
following it, and a verb, do we have a Subj-A or a Subj-B? In other words, if the subject is both clause-initial and in the second to last slot before the predicate, which should be regarded as the primary choice? Cases like this need some further elaboration. In this study they are regarded as sentenceinitial (Subj-A), because - as shown in the following - Subj-B is connected to particular pragmatic circumstances, which do not occur with sentences including only a subject, DO and predicate.

As demonstrated in Section 2, the primary topic of the utterance occupies the syntactic function of subject, and this causes variation between different syntactic structures. At the same time, the most topical elements are placed in the sentence-initial position. As a result of these two tendencies together, the syntactic subject is often in the sentence-initial position. If the SA/SP is not following a scene-setting local, directional or temporal adverbial, it occupies the sentence-initial position. In my data, $63 \%$ of the sample entries include an explicitly marked syntactic SA or SP. In $71 \%$ of the sentences with a subject, the SA/SP argument occupies the sentenceinitial slot. This number includes also the cases where the SA/SP argument is in Slot 1 and all slots from slots 2 to 7 are empty. In 29\% of these cases, Slot 7 is occupied by the SA/SP. (See Appendix.)

Variation between Subj-A and Subj-B in both active and passive is briefly demonstrated in examples (15-18). In the first two, the SA or SP is placed in sentence-initial position. In both (15) and (16) the syntactic subject is the primary topic of the sentence. Example (15) is from a folklore tale about a Mansi man called Zakhar and what happened to him one winter. The third-person singular subject is not only the primary topic of this sentence, but also the narrative topic of the story.

SA:1-Dir:6-V:9

(15)

$\begin{array}{lll}\text { Cāхарка } & \text { во̄р-н } & \text { мина-с. } \\ \text { Sāxarka } & \text { wōr-n } & \text { mina-s. } \\ \text { Zakhar } & \text { forest-LAT } & \text { go-PST.3SG } \\ \text { 'Zakhar went to the forest.' (LS 15/2017) }\end{array}$

Example (16) is from a news article about children who were taken to the forest to participate in traditional activities. The children are the narrative topic and also the primary topic of this sentence. In the sentence it is stated that before doing hunting exercises they were given bows and arrows. Arrows and bows are the focal elements of the clause. The children, i.e. the 
semantic recipient of the clause, represent the primary topic and for that reason it occupies the syntactic function of subject. A passive structure is chosen:

SP:1-IO:8-V:9

$\begin{array}{lll}\text { (16) Та̄н ёвт ос ло̄мт-ыл май-вё-с-ыт. } \\ \text { Tān jōwt is lōmt-əl } & \text { maj-wē-s-ət. } \\ \text { 3PL bow and arrow-INs } & \text { give-PASS-PST-3PL } \\ \text { 'They were given bows and arrows.' (LS 21/2018: 4) }\end{array}$

Subjects preceded by a conjunction are regarded here as SA/SP-initial clauses. A conjunction can be placed in several positions, but it does not influence the order of the other constituents. In example (17) we have a subordinate clause beginning with a conjunction (Slot o), followed by the SA/SP (Slot 1).

Conj:0-SA:1-Inf+Neg: $8^{8}-\mathrm{V}: 9$

(17) Хоты хо̄тпа-т ёхтал-анкве ат вёрм-ыс-ыт [...]

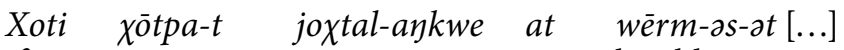

if person-PL arrive-INF NEG be.able-PST-3PL

'In case people are not able to come [to the health centre]...'

(LS 20/2018: 4)

In examples (18-20) a temporal or locational expression occupies the sentence-initial position, a locational expression follows it, and the syntactic subject comes just after these (Slot 7). In other words, the order of other constituents does not change, but the subject is postposed at Slot 7, just after the adverbials. The subject is included in an utterance describing something that happened during the mentioned period of time or at a particular location.

This kind of adverbial expression is called a scene-setting adverbial (see Section 1). The nature of scene-setting adverbials in different languages has been discussed in the literature. An important observation from the

8. In this template, the placement of several components of a complex predicate may overlap in Slot 8 . In this case, both an infinitive and a negation particle are placed in the same slot. Consequently, both are calculated in the total number of occupancies. This exceptional arrangement concerns only parts of complex predicates - for more details see Section 5.5 . 
point of view of this study is that scene-setting adverbials are placed within the topic field (see e.g. Benincà \& Poletto 2004). Further, for example Rizzi (2004) has stated that they are not part of the topic, as they do not correspond to the definition of topic, but rather they occupy an independent position. As proven by my data, scene-setting adverbials share the sentence-initial position with the topic, but there is no need to call them topics. The subject does not lose its (inherent) topicality as in (18), but as a scene-setting element, an adverbial occupies the sentence-initial position, and the subject occupies Slot 7.

Temp:2-Loc:3-SA:7-V:9

$\begin{array}{lllllll}\text { (18) Та̄л сыс } & \text { округ } & \text { янытыл } & \text { ам } & \text { са̄в } & \text { ма̄-т } \\ \text { Täl sis } & \text { okrug } & \text { janitəl } & \text { am } & \text { sāw } & m \bar{a}-t \\ \text { year during } & \text { district } & \text { around } & \text { 1SG } & \text { a.lot.of } & \text { land-PL } \\ & & & & & \\ \text { яласа-с-ум [...] } & & & & & \\ \text { jalasa-s-um [...] } & & & & \end{array}$

'During this year I have visited a lot of places around the whole district [... ]' (LS 1/2018: 6)

In example (19), the temporal adverbial appears as a scene-setting adverbial. The clause is from an article about a communal house-building project. In the previous sentences it has been mentioned that new houses are being built, and also the Sartyn'ya village has been mentioned among the involved areas. However, the temporal expression "this year", which is actually new information, is placed at sentence-initial position, because it sets a temporal framework within which the main predication holds.

Temp:2-Loc:3-SP:7-V:9

(19) Ты та̄л Сортыңъя-т кит йильпи кол-ыг

Ti tāl Sortinja-t kit jilṕpi kol-əy

this year Sartynya-Loc two new house-Du

уेнтту-ве-с-йг [...]

$\bar{u} n t t u-w e-s-\bar{y} \gamma[\ldots]$

build-PASS-PST-3DU

'This year, two brand-new houses were built in Sartyn'ya [...]' (LS 1/2018) 
Further, as stated above, in some rare cases the scene-setting adverbial is placed at Slot o in my template. In those cases the subject is placed at Slot 1, other adverbials follow it, but the scene-setting adverbial precedes it. In example (20) the subject follows the temporal adverbial, and other constituents occupy their normal slots.

Temp:o-S:1-Dir:6-Inf:8-V:9

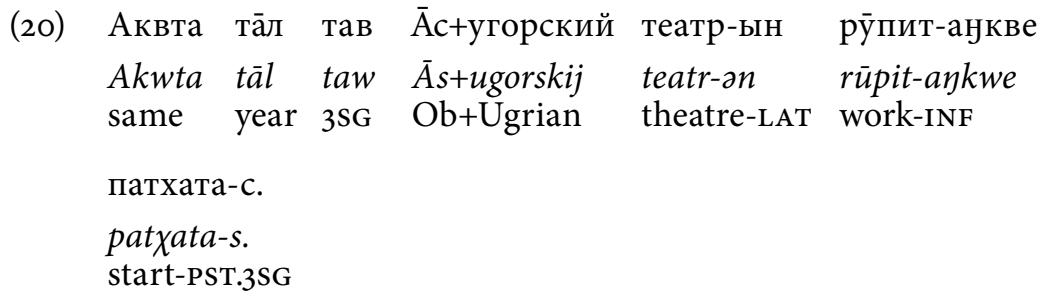

'During the same year, he started to work for the Ob-Ugrian theatre.' (LS 21/2018: 2)

Example (21) shows a typical polar question without a question word, provided only with intonation. The locational expression 'at home' is not a topical element, while the second-person singular pronoun and 'mother tongue' are in this context, but as a scene-setting adverbial it occupies the sentence-initial position:

Loc:0-SA:1-Man:4-V:9

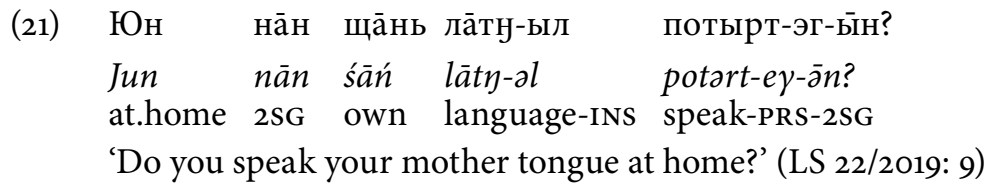

Finally, it is relevant to ask whether SAs and SPs behave in the same way. In other words, is there any difference between active and passive clauses? My data include 332 active entries with an explicitly expressed subject, and 89 passive entries with an explicitly expressed subject. Of these, $74 \%$ of the active subjects are placed in Slot 1, while the corresponding figure for the passive is $63 \%$. The difference of eleven percentage points is perhaps not remarkable in this context, but possible differences between subjects of active and passive clauses remain a question for further studies. 


\subsection{Placement of DOs, IOs and directional adverbials}

In this subsection I will discuss the linear placement of direct and indirect objects and directional adverbials. As described in Sections 1 and 4.2, indirect objects include two morphosyntactic forms: semantic recipients of ditransitive clauses marked with the lative case, and semantic themes of ditransitive clauses marked with the instrumental. The category of directional adverbials includes both lative-marked (semantic Goal) and ablative-marked (semantic Source) expressions of direction. These functions share many common functional features: DOs and instrumental-marked indirect objects (IOs) represent the same semantic role, the patient or theme. Directional adverbials - ablative- and lative-inflected directional nouns - are very close to lative-marked IOs, also because half of them are marked with the same morphological case, the lative. The ablative-marked directionals include also possessive adverbials, e.g. human referents appearing in the semantic role of source. My data prove that the syntactic behaviour of directional adverbials is closer to that of IOs than, for example, locational adverbials.

Moreover, these syntactic functions share many features concerning their placement inside the syntactic template. Slot 6 is here called the D-slot; the letter D refers to the mutual initial letter of two of the three functions, and the very adjacent phenomenon of "ditransitive". This slot is mainly occupied by lative-marked IOs, directional adverbials and DOs. Furthermore, the placement of these D-arguments is mainly divided between slots 6 and 8 . Slot 4 can also be occupied by a D-argument, but much less frequently. The division is very clear: when the arguments in question are focal, they are placed in Slot 8, while in other cases they are placed in Slot 6. Many of the D-arguments placed in Slot 6 are also secondary topics (see Section 2) of the corresponding sentences, especially DOs.

For example, Skribnik (2001: 223) and Bíró (2015: 55) have already shown that the focal argument is always placed immediately before the predicate. In my analysis this means Slot 8 , and my data strongly support their observations. Placing the most focal argument in Slot 8 explains a lot about the variation between placements of $\mathrm{D}$-arguments (and of other arguments presented in Sections 5.5 and 5.6). This is demonstrated by the following examples (22-30).

Example (22) is from a story about a man and his family. His life changed when his father was called up to the army. The expression 'call up to the army' is mentioned for the first time here and is the focus of the sentence, so the directional expression occupies the focus slot: 
SP:1-Temp:2-Dir:8-V:9

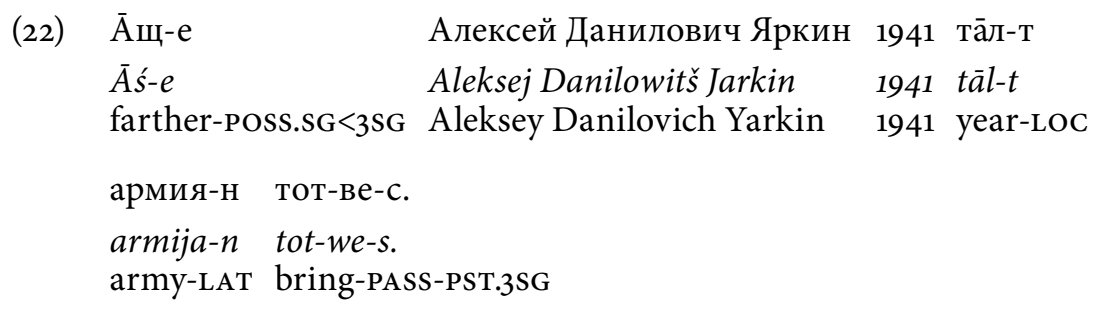

'In 1941, his father Aleksey Danilovich Yarkin was called up to the army.' (LS 9/2014: 13)

In (23), both the first-person and third-person singular referents are inherently topical elements, and the new information is that the speaker is sending greetings. The topical (secondary topic) IO is placed in Slot 6, and the focal DO in Slot 8.

SA:1-IO:6-DO:8-V:9

$\begin{array}{llll}\text { (23) Ам тав-е̄н паща па̄тың ке̄т-э̄г-ум. } \\ \text { Am taw-ēn paśa lātay kēt-ē } \gamma \text {-um. } \\ \text { 1SG } 3 \text { 3SG-LAT greeting } & \text { speech } & \text { send-PRS-1SG } \\ \text { 'I send him my greetings.' (LS 9/2014: 13) }\end{array}$

As mentioned earlier, a nominal DO normally follows the subject and precedes the predicate, but its placement is not restricted to the slot immediately before the verb. A DO can also be followed by IOs or temporal, locational or other adverbials, if any of them is in a focus position. In my data, $50 \%$ of all DOs are placed in Slot 6 (D-slot), $45 \%$ in Slot 8 and the rest - more marginal cases that are not discussed here - in other slots. This variation can be explained by pragmatic reasons. Those DOs appearing in Slot 6 are also pragmatically classified as secondary topics (see Section 2). $99 \%$ of all DOs placed in Slot 6 are also accompanied by the objective conjugation. Correspondingly, those DOs placed in Slot 8 are pragmatically classified as foci, and they are accompanied by the subjective conjugation.

The following three examples (24-26) include a DO immediately preceding the verb. As can be seen from the context, in all of them the DO is the most focal argument of the clause. For that reason these DOs are also accompanied by the subjective conjugation (for comparison, see 27-28). In (24), the speaker has spoken about her career in the immediately preceding sentences, and she mentions the report for the first time. The focus of the sentence is what she is doing at the time: 


\section{Constituent order in Northern Mansi}

Temp:2-DO:8-V:9

(24) Ань доклад+нэ̄пак щёпит-э̄г-ум.

Ań doklad+nēpak śōpit-ē $\gamma$-um.

now report+book prepare-PRS-1SG

'Currently I'm writing a report.' (LS 1/2018: 6)

Example (25) describes the situation in a village. In the previous sentences it has been explained what other things villagers do for a living, and here fishing is added to the list:

SA:1-DO:8-V:9

(25) Ма̄хум хӯл алыщл-э̄г-ыт.

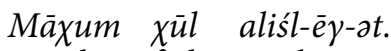

people fish catch-PRS-3PL

'People go fishing.' (LS 9/2014: 13)

Example (26) is from a story about an old man's life: first it is told that he lived in a sovkhoz and worked as a fisherman. This sentence is about the next step: later on he did many kinds of work in the same sovkhoz.

Man:2-Loc:3-DO:8-V:9

(26) Ты коныпал совхоз-т са̄всыр рӯпата ва̄р-ыс.

Ti konipal sowxoz-t sāwsar rūpata wār-əs.

this in.addition sovkhoz-LOC many.kinds work do-PST.3sG

'Besides that, he did many kinds of work at the sovkhoz.' (LS 9/2014: 13)

In both (27) and (28), the DO is placed in the sixth slot. The DO is the secondary topic of the clause (see Section 2) and accompanied by the objective conjugation. In (27) the DO is followed by a manner adverbial, and in (28) by a temporal adverbial. In (27) a speech has been discussed earlier, and it is mentioned for the first time that it was in Mansi (not in Russian):

SA:1-DO:6-Man:8-V:9

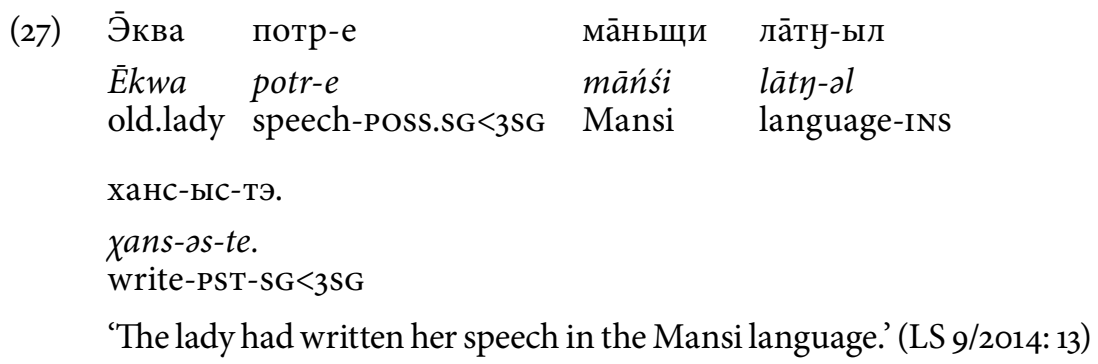


In (28), the man has already seen a reindeer watching him, and the reindeer tells the man that he has been following him for a while. The man is the secondary topic and accompanied by the objective conjugation. The temporal expression is the focal element of the clause:

SA:1-DO:6-Temp:8-V:9

$\begin{array}{lllll}\text { Aм науын хосат та̄гыл } & \text { ва̄г-лум }[\ldots] \\ \text { Am nayan } & \text { xosat } & \text { tāyal } & \text { wā } \gamma \text {-lum } & {[\ldots]} \\ \text { 1SG } & \text { 2SG.ACC } & \text { long.time } & \text { completely } & \text { know-SG<1SG } \\ \text { 'I know you very well, for a long time now [...]' (LS 15/2017: 15) }\end{array}$

Instrumental-marked IOs are placed immediately before the verb (Slot 8) in $99 \%$ of cases, because they tend to be focal. When a speaker chooses the right sentence structure for the situation (see Section 2), the focal patient is placed in the syntactic function of IO. In other words, the pragmatic variation between different three-participant constructions only allows a focal argument to occupy the syntactic function of IO.

Example (29) is from a news article about people with accommodation problems, stating that the poor family in question was given a special kind of house by the authorities.

SP:1-IO:8-V:9

(29) Та̄н тамле кол-ыл май-вё-с-ыт.

Tān tamle kol-al maj-wē-s-at.

3PL like.that house-INS give-PASS-PST-3PL

'They were given a house like that.' (LS 1/2018: 5)

In (30) the people in question have participated in a snow-sculpture competition, and the reader knows that they have won first prize. The new information is that they were given a diploma for their work:

SP:1-Man:4-IO:8-V:9

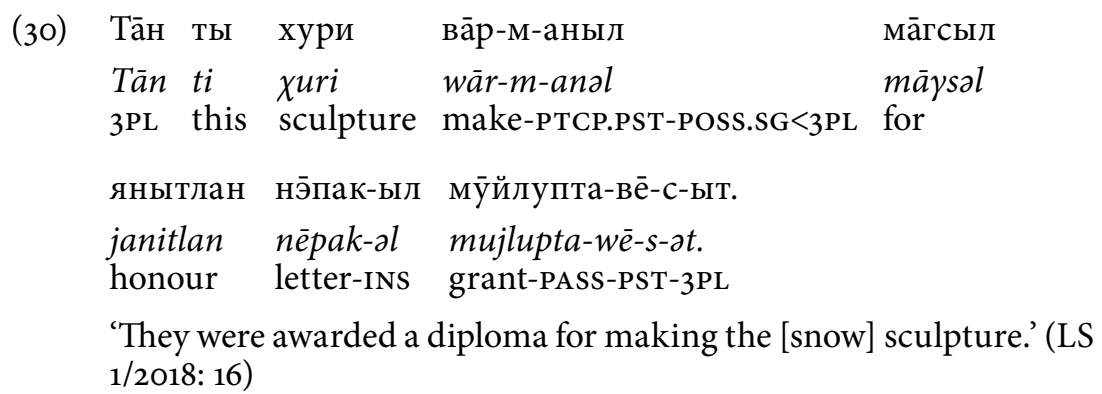


The following table describes the placements of DOs, directives, DOs and IOs. The table describes how the pragmatic variation between different sentence structures (see Section 2) affects the placement of individual syntactic functions. DOs and directional adverbials represent both pragmatic secondary topics and foci - and vary between the two slots correspondingly - while instrumental-marked IOs tend to be foci and occupy Slot 8. The placement of lative-marked IOs is very concentrated in Slot 6, and the most focal ones are placed at Slot 8.

Table 3: Placement of D-arguments

\begin{tabular}{lccc}
\hline & 6. (Neutral/Secondary Topic) & 8. (Focus) & other \\
\hline $\begin{array}{l}\text { Directional adverbials } \\
\text { (lative, ablative) }\end{array}$ & $79 \%$ & $13 \%$ & $8 \%$ \\
DOs & $50 \%$ & & \\
IOs (lative) & $88 \%$ & $45 \%$ & $5 \%$ \\
IOs (instrumental) & $17 \%$ & $12 \%$ & - \\
\hline
\end{tabular}

\subsection{Placement of adverbials: time, location and manner}

According to my data, the placement of adverbials is relatively regular and easy to explain. Temporal, manner and locational adverbials have their own slots, which they occupy with some exceptions due to pragmatics. ${ }^{9}$ In short, Slot 2 is for time, Slot 3 for location and Slot 4 for manner. In the event that there is more than one adverbial of any type in one clause, the last one is placed at Slot 5. As described in Section 5.4, Slot 8 is for the most focal argument of the clause, and it can also be occupied by focal adverbials of time, location and manner.

The placement of temporal expressions is concentrated in Slot 2, which supports Rombandeeva's views (see Section 1). In $72 \%$ of cases in my data, temporal expressions are placed in Slot 2. Further, 13\% of temporal expressions are placed in Slot o due to their scene-setting status (see Section 5.2), $11 \%$ in Slot 5 , and $4 \%$ (the focal ones) placed in Slot 8.

Example (31) is from the beginning of a news text about the Russian president's visit to Khanty-Mansiysk. The president is the narrative topic and also the clausal primary topic. The temporal adverbial is in the default position.

9. Adverbials of location, manner and time appearing as scene-setting adverbials are discussed in Section 5.2. 
SA:1-Temp:2-Man:4-Dir:6-V:9

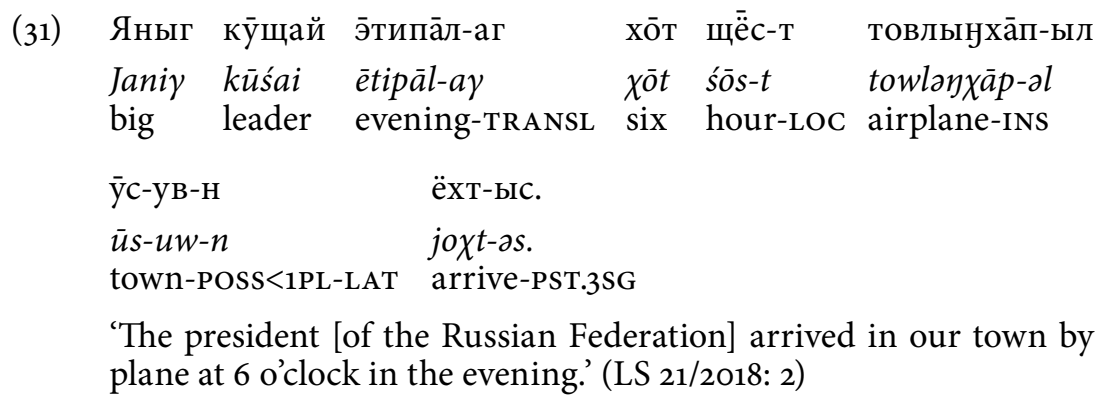

Example (32) is from the story about the old man, Ekur. The previous sentences have explained where he studied and what he did during his studies. The story continues here. Again, the temporal adverbial is in the default position.

SA:1-Temp:2-Temp:5-Pred:8-V:9

(32) Екур Тобольский рыбтехникум а̄стла-м-е

Ekur Tobolśkij ribtexnikum āstla-m-e

Ekur Tobolsk.ADJ college.of.fishery graduate-PST.PTCP-POSS.SG $<3$ SG

юипа̄лт са̄в та̄л рыбак-ыг рӯпита-с.

juipālt sāw tāl ribak-y rūpita-s.

after many year fisher-TRANSL work-PST.3SG

'After graduating from the College of Fishery in Tobolsk, Ekur worked for many years as a fisherman.' (LS 9/2014: 13)

As already stated in 5.2, in some cases (22\% of all entries with a scene-setting adverbial) the scene-setting adverbial is placed at Slot o in my analysis. In these examples, all the other arguments - including subjects - occupy their regular slots, while the scene-setting adverbial is placed at the very beginning of the clause. In other words, the subject is not placed at Slot 7: it appears at Slot 1 before the other adverbials, but following the scenesetting one. In (33), the temporal expression is in a scene-setting function and placed at Slot o. Interestingly, the subject of the clause is not a topical expression but belongs to an all-in-focus structure. The uncle of the man referred to with a possessive suffix is mentioned for the first time. The fact that he started to learn dancing and playing is new information as well. 


\section{Constituent order in Northern Mansi}

Temp:o-S:1-Dir:6-V:9

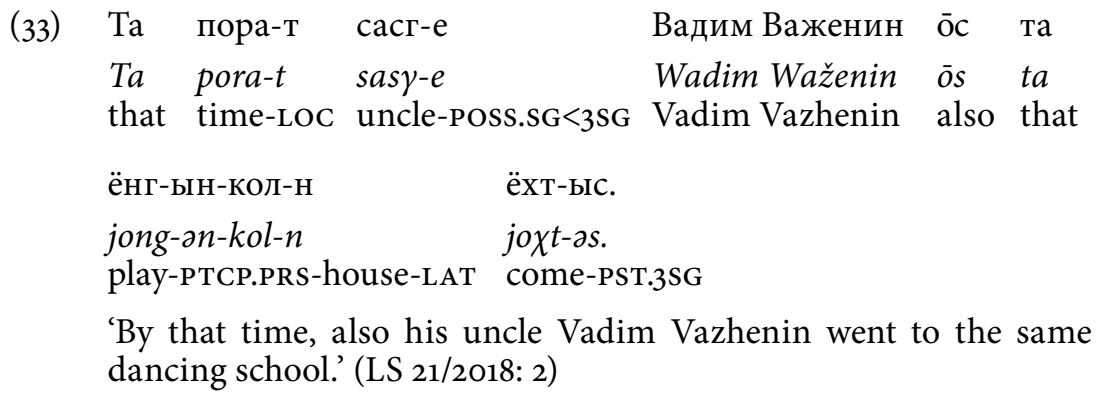

Locational expressions ${ }^{10}$ are placed in slots $3(78 \%)$ and $5(14 \%)$ - except the most focal ones, which are placed in Slot $8(6 \%)$, and those representing scene-setting adverbials at Slot o (2\%). In this phase of the analysis, I faced the question of how to distinguish an adverbial in Slot 3 from one in Slot 8, if there is only a subject, an adverbial and a verb in the sentence (see also Section 5.3). The question was solved in the final phase of the analysis by comparing the pragmatic analysis to the templatic order: if the adverbial is recognized as a focus in the pragmatic analysis, it is placed in Slot 8 , and if not, it is placed in Slot 3 .

In both (34) and (35) there is a local expression in Slot 3. Both sentences are drawn from articles about people's life stories: in (34) the local expression is a deictic pronoun, referring to a location mentioned in the previous sentence, and already familiar to the reader. The focus of the sentences is the temporal expression:

SA:1-Loc:3-Temp:5-V:9

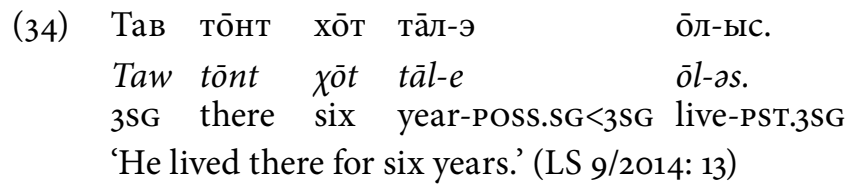

In (35), the expression of location is the focus of the sentence and placed in Slot 8 . The new information in the sentence is the adverbial answering the question about where the interviewed old man was born.

10. In this point my approach differs from Rombandeeva's: I discuss directional and locational expressions separately. Directional adverbials are discussed in Section 5.3, and they have more in common with dative adverbials. 
SA:1-Loc:8-V:9

$\begin{array}{llll}\text { (35) Тав Ха̄льӯс } & \text { район } & \text { Саранпа̄выл-т } & \text { сам-ын }^{11} \\ \text { Taw Xālús } & \text { rajon } & \text { Saranpāwal-t } & \text { sam-ən } \\ \text { 3Sg Beryozovo } & \text { district } & \text { Saranpaul-LOC } & \text { eye-LAT } \\ & & & \\ \text { пат-ыс }[\ldots] & & & \\ \text { pat-əs }[\ldots] & & & \\ \text { become-PST.3SG } & & \end{array}$

'He was born in Saranpaul in Beryozovo District [...]' (LS 21/2018: 2)

In (36), there are two locational adverbials. The first was mentioned recently, but the second and more specific one is new information. The first local adverbial in Slot 3 refers to Beryozovo, where the man was said to have lived. The second is the focus of the sentence specifying the location or employer where he started to work in Beryozovo, building some new houses.

SA:1-Loc:3-Loc:8-V:9

(36) Павел Владимирович ты ӭлы-пал Ха̄льӯс миркол-т

Pavel Wladimirovitš ti èli-pal Xālūs mirkol-t

Pavel Vladimirovich this before Beryozovo municipality-LOC

\begin{tabular}{|c|c|c|c|c|}
\hline кол-ыт & уेнтт-ын & Mā-t & рӯпита-с & {$[\ldots]$} \\
\hline $\begin{array}{l}\text { kol-ət } \\
\text { house-PL }\end{array}$ & $\begin{array}{l}\bar{u} n t t-\partial n \\
\text { build-PTCP.PRS }\end{array}$ & $\begin{array}{l}m \bar{a}-t \\
\text { land-LOC }\end{array}$ & $\begin{array}{l}\text { rūpita-s } \\
\text { work-PST.3S }\end{array}$ & \\
\hline
\end{tabular}

In (37), the scene-setting locational adverbial occupies Slot o, and the focal temporal adverbial follows it at Slot 2 . There is no overt subject: as a highly topical element it is only referred to with a verb ending (zero anaphora). The name of the village (Southern Narykary) provides the framework within which the main predication holds, and the new information provided is the length of time the old man spent in the village.

Loc:o-Temp:2-Loc:8-V:9

(37) Алы Нярихуми-т мат-нэ̄-тэ мус

Ali Narixumi-t mat-nē-te mus

Southern Narykary-LOC get.old-PRS.PTCP-POSs.SG<3SG until

11. Самын патункве 'become visible' is a phrase meaning 'be born'. The lativeinflected noun is a part of the verb, not a separate constituent. 
$\begin{array}{lll}\text { тохин } & \text { тот } & \text { олл-ыс. } \\ \text { toxin } & \text { tot } & \bar{o} l \text {-əs. } \\ \text { this.way } & \text { there } & \text { live-PST.3SG }\end{array}$

'He lived in Southern Narykary in the same way until he got old.' (LS 9/2014: 13)

Manner adverbials are most frequently placed in Slot 4: 75\% of the manner adverbials in my data are placed in Slot $4,19 \%$ in Slot 8 due to their focus position, and $6 \%$ in Slot o due to their scene-setting function. Manner adverbials include adverbs (often identical with adjectives) and postpositional phrases. Example (38) is from a news text about a public event and represents a typical neutral declarative sentence. The manner adverbial is placed in its default position, before the local adverbial.

SA:1-Man:4-Loc:5-V:9

\begin{tabular}{|c|c|c|c|}
\hline & ща̄гт-ым & тот & ха̄йтыгт-э̄г-ыт \\
\hline & $\begin{array}{l}\text { śāyt-am } \\
\text { glad-ADV }\end{array}$ & $\begin{array}{l}\text { tot } \\
\text { there }\end{array}$ & $\begin{array}{l}\chi \bar{a} j t a \gamma t-\bar{e} \gamma \text {-at } \\
\text { run.around-PRs }\end{array}$ \\
\hline
\end{tabular}

'Children were running around there happily [...].' (LS 1/2018: 16)

The order in (39) is exceptional in my data: the topical DO is placed in Slot 4, with the manner adverbial directly following it. This is rare from the perspective of syntactic order, but from a pragmatic point of view it is quite natural: from context we know that the horned head of the reindeer is an accessible argument, but the way he shakes it is not. In the immediately preceding sentences, we learn that the reindeer got new horns from the humans. Now the animal is proud of the horns: pride is the focal phenomenon.

SA:1-DO:4-Man:6-V:9

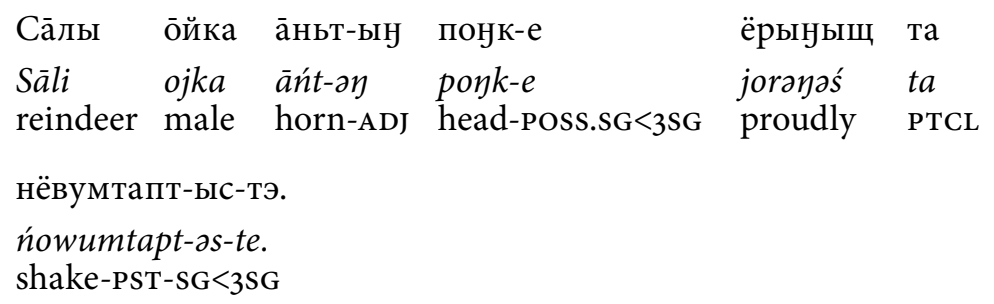

'So the reindeer shook his horned head proudly.' (LS 15/2017: 15) 
Finally, 17 samples in my data belong to the group "other adverbials". As mentioned above, "other adverbials" include, for example, adverbials of reason or condition, and they behave in the very same way as the adverbials of time, location or manner. Most of them function as scene-setters and are placed at Slot 0.

\subsection{Placement of agent adverbials, negation particles, nominal predicates and infinitives}

Quite a diverse group of functions share the same slot within the syntactic order: agent adverbials, negation particles and nominal predicates (including nouns, adjectives and participles), and the infinitives. Their syntactic functions are very systematically placed at Slot 8 . However, there are two distinctive reasons for the appearance of these functions in the aforementioned slot. First, agent adverbials represent pragmatically focal arguments. This is a natural consequence of the fact that focal arguments tend to occupy syntactic non-core positions and occur inflected in oblique cases. If a semantic agent were topical, it would appear as a syntactic subject. In the event that a semantic agent is focal, it appears as a syntactic agent and is inflected in the lative case. Secondly, negation particles, infinitives and participles are closely related to the finite verb: they are parts of complex predicates $^{12}$ (see e.g. Alsina et al. 1997; Amberber et al. 2010).

The placement of infinitives is indicated in Appendix, but detailed further conclusions concerning them are not presented. The infinitive is not a syntactic function, but it is a syntactic phenomenon in many ways. In my data, $90 \%$ of the infinitive forms are placed in Slot 8: this is not because they all are focal but because they belong to complex predicates. Participle forms of verbs are not a separate group in the table in Appendix, because there are only a few of them, but they are included in the group of nominal predicates. It is still worth mentioning that those few occurrences are placed immediately before the verb.

As demonstrated in previous sections, Slot 8 is the default slot of the pragmatic function of focus. In addition, as described above, it is a default slot for elements that are parts of complex predicates. One of the most typical components in Slot 8 in my analysis is the negation particle (see

12. Complex predicates are predicates which are composed of more than one grammatical element (either morphemes or words), each of which contributes a nontrivial part of the information of the complex predicate (Alsina et al. 1997). 
also Wagner-Nagy 2011: 80-81). Example (40) is from a newspaper article about a community-supported house-building project to help poor families. In the previous sentences, it has been told how many families and what amounts of money are involved. Now it is mentioned that the money is not paid in cash directly to the families.

SP:1-Dir:6-Neg:8-V:9

(40) Ты олн-ыт ка̄т-ын ат ми-ве-т.

Ti oln-at kāt-an at mi-we-t.

this money-PL hand-LAT NEG give-PASS-PRS.3PL

'This money is not given in cash.' (LS 1/2018: 13)

Nominal predicates are predicative elements, or at least parts of complex predicates, but also inherently focal elements: their function is to give more information about the features of something which is already accessible. Mansi is a language where adjectival and some nominal predicates appear without copula. In my data, $73 \%$ of all nominal predicates are placed in Slot 8 , as in (41): these ones are accompanied by a Verb. The further $15 \%$ are placed in Slot 9: these are nominal predicates without a copula (42). The remaining $12 \%$ appear in Slot 4.

SA:1-Pred:8-V:9

(41) Са̄харка колта̄гыл ма̄хм-анэ ёт ӧлупса-ныл Sāxarka koltāyal māxm-ane jot ōlupsa-nal Zakhar family people-POss.PL $<3$ PL with life-POSs.PL $<3$ PL

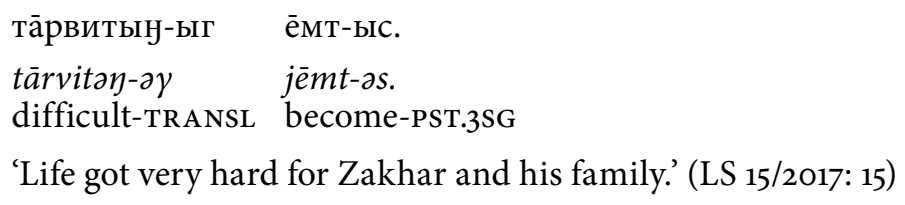

'Life got very hard for Zakhar and his family.' (LS 15/2017: 15)

As described above, sometimes a nominal predicate or a participle occupies Slot 9 instead of a (finite) Verb (42). That is because the nominal predicate appears without a copula and fulfils the same functions that the verb normally does. Example (42) is from a folklore tale about a man living in the Urals. In the previous sentences, the reader learns that winter has come. The focus of this sentence is on what the winter is like. The sentence is built from a shared scene-setting adverbial and two independent clauses with a subject and a nominal predicate, connected together with a conjunction. 
Loc:3-SA:7-Pred:9-Conj-SA:7-Pred:9

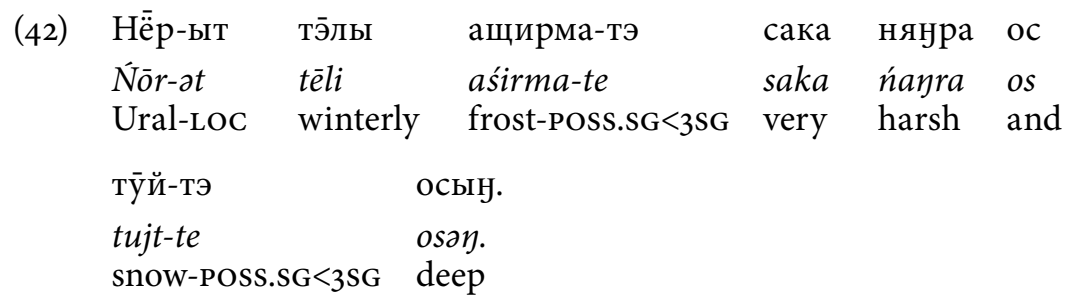

'In the Urals the winter frost is very harsh, and the snow is deep.' (LS 15/2017: 15)

\subsection{Question words and interrogative structures}

Finally, some attention has to be paid to questions. In many languages, the constituent order of interrogative sentences is different from that of declarative ones. In Mansi, interrogative sentences are produced in a very similar way to declarative sentences. A more detailed picture would require a separate study based on more extensive question data, but according to the few questions appearing in my data, the constituent order proves to be not so different from that presented above. In wh-questions, the question word normally occupies the focus slot, and the other constituents are placed similarly as in declarative clauses.

We can see that both (43) and (44) are SA/SP-initial, verb-final sentences, where the wh-word occupies the focus slot:

Addr:o-SA:1-Loc:3-V:9

(43) Дмитрий Игоревич, нау хо̄т яныгма-с-ын?

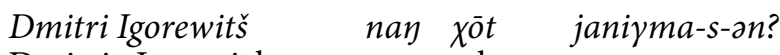

Dmitriy Igorevich 2SG where grow.up-PST-2SG

'Dmitriy Igorevich, where did you grow up?' (LS 1/2020: 12)

SP:1-WH:8-V:9

(44) Акв тамле ковёр манах хо̄тал ва̄р-аве?

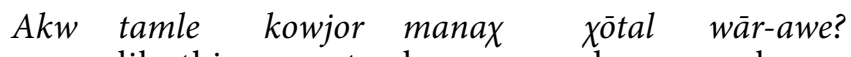

one like.this carpet how.many day make-PAss.PRS.3SG

'How many days does it take to make a carpet like this?' (LS 1/2020: 13)

Polar questions are produced without separate interrogative structures: in speech the question is expressed with intonation, and in writing with a question mark. The constituent order follows the rules presented above, as in (45) and (46): 


\section{Constituent order in Northern Mansi}

Loc:3-SA:7-V:9

$\begin{array}{lllll}\text { (45) Па̄вл-анын-т ат а̄стл-ым } & \text { кол-ыт } & \text { олл-э̄г-ыт? } \\ \text { Pāwl-anən-t } & \text { at } & \bar{a} s t l-\partial m & k o l-\partial t & \bar{o} l-\bar{e} \gamma \text {-ət? } \\ \text { village-2PL-LOC } & \text { NEG } & \text { prepare-PTCP.PST } & \text { house-PL } & \text { be-PRS-3PL } \\ \text { 'Are there any not ready-built houses in your village?' (LS 1/2018: 5) }\end{array}$

SA:1-Loc:3-V:9

$\begin{array}{lll}\text { (46) Сӯкыръя } & \text { Саранпа̄выл } & \text { ляпат о̆л-ы? } \\ \text { Sūkarja } & \text { Sapanpāwal l'apat ōl-i? } \\ \text { Shchekur'ya } & \text { Saranpaul near be-PRS.3SG } \\ \text { 'Is Shchekur'ya village situated near Saranpaul?' (LS 22/2019: 13) }\end{array}$

\section{Results, conclusions and further questions}

In this article, I have presented a template-based analysis of Northern Mansi constituent order. Northern Mansi is a language where information structure is primarily expressed with syntactic variation between active and passive and between different clause types, but also the constituent order is connected to information structure. My analysis enables simultaneous observation of both the syntactic and pragmatic levels. The preceding section showed how syntactic functions occupy constituent order positions. Most of the functions have two or three alternative slots, and the position of a syntactic function varies between them. Within the 9+1 slots, there are very obvious alternation pairs which behave systematically in the data, and the reasons for this variation are pragmatic.

After recognizing and distinguishing the most typical types of order of syntactic functions, I connected a pragmatic level to the analysis. I added the pragmatic functions primary topic, focus, scene-setter and neutral. Table 4 shows how these pragmatic functions fit the model of ten syntactic slots. Some slots are primarily occupied by syntactic functions. When the placement of one syntactic function alternates between two slots, this can be explained by pragmatic reasons. Some slots are primarily reserved for particular pragmatic functions, and the position of the syntactic functions varies a lot. For example, the syntactic subject appears in the clause-initial position when representing the pragmatic primary topic, and closer to the clausefinal verb when there is a scene-setting temporal or locational adverbial. 
Table 4: Placement of syntactic and pragmatic functions in the $9+1$ slot model. (An empty cell means that the pragmatic or syntactic perspective is not relevant to the slot in question.)

\begin{tabular}{lll}
\hline Slot & Pragmatic default & Syntactic default \\
\hline O & Scene-setter & \\
1 & Primary Topic & Subject \\
2 & & Time-1 \\
3 & & Loc-1 \\
4 & & Manner \\
5 & & Loc-2/Time-2 \\
6 & Neutral/Secondary Topic & D \\
7 & & Subject \\
8 & Focus & \\
9 & & Predicate (verb or nominal predicate) \\
\hline
\end{tabular}

The default placement of the subject is in the sentence-initial position, possibly preceded by a conjunction. This tendency is connected to the topicality of the syntactic subject: in transitive structures, the pragmatic role of primary topic occupies the syntactic function of subject. The most topical arguments tend to occupy sentence-initial positions. When the subject is placed near the predicate to Slot 7, only a few particular arguments can be placed between them. According to my data, these arguments are 1) instrumental-inflected IO, 2) agent adverbial, 3) DO and 4) the infinitive or participle form of a verb, which belongs to a complex predicate. The most focal argument is placed immediately before the predicate. Because of the pragmatic variation between the different clause structures (see Section 2), this cannot be any argument: the most topical elements are placed in syntactic core roles. The most typical syntactic functions expressing the pragmatic focus function are DO, IO, directional adverbial, agent adverbial and nominal predicate.

In my data, the arrangement of constituent order is twofold. First, the basic constituent order is connected to the order of syntactic functions. Mansi is basically an SOV language. Secondly, particular syntactic functions alternate between two or more slots, depending on which pragmatic function they represent. Some slots are always occupied by a particular pragmatic function, which can be represented by several syntactic functions.

The main results of the syntactic and pragmatic analyses are: 
1. The same template model can be applied to both active and passive clauses, and to different clause types.

2. The verb - or in the case of a clause without a copula, a nominal predicate - occupies the clause-final position, possibly followed only by conjunctions or other particles.

3. Topical arguments tend to occupy sentence-initial positions.

4. The most focal element is always placed in Slot 8 , immediately before the verb.

5. The placement of the subject (SA/SP) varies between two slots: sentence-initial and two slots before the verb. Variation is due to pragmatic motivation.

6. DOs, IOs and directional adverbials share various common features both semantic and syntactic - and common slots.

7. Temporal, locational and manner adverbials are placed immediately after the SA/SP, with the temporal component always coming first. When there is a clause-initial scene-setting adverbial, it is placed before the subject.

Finally it is worth mentioning that many of my results are identical or similar to the observations of Rombandeeva (1984: 58-60) on Mansi word order. My data wholly support Rombandeeva's statements about the subject and its attributes always preceding the predicate, the predicate always attending the sentence-final position, adverbials preceding the predicate, and the direct object usually being between the subject and the predicate. Also her statements that a focal expression of location is placed immediately before the predicate, and attributives always immediately precede the word they belong to, are wholly supported.

Further, the differences between Rombandeeva's observations and my results concern the placement of expression of time and location. According to Rombandeeva, the expression of time always precedes the subject and is placed in the sentence-initial position. My data show quite clearly that the expression of time precedes the subject only when it is in a scenesetting function. The default placement of temporal adverbials is in Slot 2, immediately after the subject. According to Rombandeeva, the expression of location is immediately before the predicate, or in the sentence-initial position. Also in this case my results differ from hers. According to my data, there are two stable slots for locational adverbials. The default placement is in Slot 3, and if there are several expressions of location in one sentence, the second one is in Slot 5. Further, the focal adverbials are placed at Slot 8. I also discussed the directional adverbials as a separate category, not 
a part of the locational adverbials. As proven by my data, locational and directional adverbials do not behave identically: locational adverbials tend to appear before the manner and directional adverbials, while the directional ones are placed after the locational and manner adverbials.

Certain more marginal details and questions concerning Mansi constituent order have been excluded from this study and will hopefully be topics of further studies. For example, the placement of conjunctions is only briefly mentioned in the analysis, while the original template showed clear tendencies for variation among conjunctions. The slight differences between the occurrence of SAs and SPs, and a detailed analysis of the placement of complex predicates should also be discussed in more detailed studies. Moreover, different kinds of marginal chain effects, i.e. a change in one property leading to changes in others, have not been presented here, but a detailed presentation of these would be very fruitful.

\section{Nonstandard abbreviations used in glosses}

$$
\begin{array}{ll}
\text { LAT } & \text { lative case } \\
\text { PTCL } & \text { particle }
\end{array}
$$

\section{Other abbreviations}

$\begin{array}{ll}\text { 1-P } & \text { 1-participant } \\ \text { 2-P } & \text { 2-participant } \\ \text { 3-P } & \text { 3-participant } \\ \text { Addr } & \text { addressing word } \\ \text { Ag } & \text { agent (semantic role) } \\ \text { AgA } & \begin{array}{l}\text { agent adverbial } \\ \text { (syntactic function) }\end{array} \\ \text { Dir } & \text { adverbial of direction } \\ & \text { (syntactic function) } \\ \text { DO } & \text { direct object (syntactic function) } \\ \text { DOA } & \text { Differential Object Agreement } \\ \text { DOM } & \text { Differential Object Marking } \\ \text { IOC } & \text { Indirect Object Construction } \\ \text { IO } & \text { Indirect object } \\ & \text { (syntactic function) }\end{array}$

\author{
STRESS stressed form (of a \\ personal pronoun) \\ TRANSL translative case
}

\section{References}

Aissen, Judith. 2003. Differential object marking: iconicity vs. economy. Natural Languages \& Linguistic Theory 21. 435-483.

Allan, Keith. 1987. Hierarchies and the choice of left conjuncts (with particular attention to English). Journal of Linguistics 23(1). 51-77.

https://doi.org/10.1017/Soo22226700011038 
Alsina, Alex \& Bresnan, Joan \& Sells, Peter (eds.). 1997. Complex predicates. Stanford: CSLI Publications.

Amberber, Mengistu \& Baker, Brett \& Harvey, Mark (eds.). 2010. Complex predicates: Cross-linguistic perspectives on event structure. Cambridge: Cambridge University Press.

BAKER, MARK. 2003. Agreement, dislocation, and partial configurationality. In Carnie, Andrew \& Harley, Heidi \& Willie, Mary (eds.), Formal approaches to function in grammar, 107-132. Amsterdam: John Benjamins Publishing Company.

Benincà, Paola \& Poletto, Cecilia. 2004. Topic, Focus and V2: Defining the CP Sublayers. In Rizzi, Luigi (ed.), The structure of CP and IP, 52-75. New York: Oxford University Press.

Bíró, BERnADETT. 2015. Az északi és déli manysi ditranzitív szerkezetek szórendje. In É. Kiss, Katalin \& Hegedűs, Attila (eds.), Nyelvelmélet és dialektológia 3, 43-57. Piliscsaba: Szent István Társulat, Az Apostoli Szentszék Könykiadója.

Bíró, Bernadett \& Sipőcz, Katalin. 2017. The Mansi ditransitive constructions. Finno-Ugric Languages and Linguistics 6(1). 41-55. http://full.btk.ppke.hu/index.php/FULL/article/view/53/59

Bossong, Georg. 1985. Empirische Universalienforschung: Differentielle Objektmarkierung in den neuiranischen Sprachen. Tübingen: Gunter Narr Verlag.

Chafe, Wallace L. 1976. Givenness, contrastiveness, definiteness, subjects and topics. In Li, Charles N. (ed.), Subject and topic, 25-55. New York: Academic Press.

Costa, James. 1997. Word order and constraint interaction (Seminários de Linguística 1), 65-102. Faro: University of the Algarve.

Costa, James. 1998. Word order variation: A constraint-based approach. The Hague: Holland Academic Graphics.

Costa, JAmES. 2001. The emergence of unmarked word order. In Legendre, Géraldine \& Grimshaw, Jane \& Vikner, Sten (eds.), Optimality-theoretic syntax, 171-204. Cambridge: MIT Press. https://doi.org/10.7551/mitpress/5161.003.0010

Dalry mple, Mary \& Nikolaeva, Irina. 2011. Objects and information structure. Cambridge: Cambridge University Press.

https://doi.org/10.1017/cbo9780511993473.004

Downing, PAmela. 1995. Word order in discourse: By way of introduction. In Downing, Pamela \& Noonan, Michael (eds.), Word order in discourse (Typological Studies on Languages 30), 1-28. Amsterdam: John Benjamins Publishing Company. https://doi.org/10.1075/tsl.30.02dow

É. Kiss, Katalin. 1995. Introduction. In É. Kiss, Katalin (ed.), Discourse configurational languages, 3-27. New York: Oxford University Press.

FläMIG, WALTER. 1991. Grammatik des Deutschen: Einführung in Struktur- und Wirkungszusammenhänge. Erarbeitet auf der theoretischen Grundlage der Grundzüge einer deutschen Grammatik. Berlin: Akademie Verlag.

Good, Jeff. 2016. The linguistic typology of templates. Cambridge: Cambridge University Press. https://doi.org/10.1017/cbo9781139057479

Greenberg, Joseph H. 1963. Some universals of grammar with particular reference to the order of meaningful elements. In Greenberg, Joseph H. (ed.), Universals of human language, 73-113. Cambridge: MIT Press. 
HALE, KEN. 1983. Warlpiri and the grammar of non-configurational languages. Natural Language and Linguistic Theory 1. 5-47.

Haspelmath, Martin. 2015. Ditransitive constructions. Annual Review of Linguistics 1. 19-41.

Hawkins, John A. 1994. A performance theory of order and constituency. Cambridge: Cambridge University Press. https://doi.org/10.1017/Soo22226796256397

Heine, Bernd \& König, Christa. 2010. On the linear order of ditransitive objects. Language Sciences 32(1). 87-131. https://doi.org/10.1016/j.langsci.2008.07.002

Höhle, Tilman. 1986. Der Begriff "Mittelfeld": Anmerkungen über die Theorie der topologischen Felder. In Weiss, Walter E. \& Wiegand, Herbert E. \& Reis, Marga (eds.), Textlinguistik contra Stilistik. Akten des VII. Internationalen Germanisten-Kongresses Göttingen 1985 (Kontroversen, alte und neue, Bd. 3), 329-340. Tübingen: Niemeyer.

Kálmán, BÉla. 1989. Chrestomathia Vogulica. (Second edition.) Budapest: Tankönyvkiadó.

Kathol, Andreas. 1995. Linearization-based German syntax. Columbus: The Ohio State University. (Doctoral dissertation.)

Kathol, Andreas. 200o. Linear syntax. Oxford: Oxford University Press.

Keresztes, LÁszló. 1998. Mansi. In Abondolo, Daniel (ed.), The Uralic languages, 387-427. London: Routledge. https://doi.org/10.4324/9781315003283

Kulonen, Ulla-Maija. 1989. The passive in Ob-Ugrian (Mémoires de la Société Finno-Ougrienne 203). Helsinki: Finno-Ugrian Society.

Kulonen, Ulla-Maija. 2007. Itämansin kielioppi ja tekstejä (Apuneuvoja suomalais-ugrilaisten kielten opintoja varten XV). Helsinki: Finno-Ugrian Society.

LAMBRECHT, KNUD. 1994. Information structure and sentence form: Topic, focus, and the mental representations of discourse referents (Cambridge Studies in Linguistics 71). Cambridge: Cambridge University Press.

LS = Лȳuмā ç̄punoc [Lūimā Sēripos]. [Newspaper published in Khanty-Mansiysk. Readable also online: http://www.khanty-yasang.ru/luima-seripos]

Malchukov, Andrej \& Haspelmath, Martin \& Comrie, Bernard. 2010. Studies in ditransitive constructions: A comparative handbook. Berlin: De Gruyter Mouton. https://doi.org/10.1515/9783110220377

VAN Riemsdijk, Henk. 2002. The unbearable lightness of GOing: The projection parameter as a pure parameter governing the distribution of elliptic motion verbs in Germanic. The Journal of Comparative Germanic Linguistics 5. 143196. https://doi.org/10.1023/A:1021251312697

Riese, Timothy. 2001. Vogul. München: Lincom Europa.

Rizzi, Luigi. 1997. The fine structure of the left periphery. In Haegeman, Liliane (ed.), Elements of grammar, 281-337. Springer: Dordrecht. https://doi.org/10.1007/978-94-011-5420-8_7

Rizzi, Luigi. 2004. Locality and left periphery. In Belletti, Adriana (ed.), Structures and beyond: The carthography of syntactic structures 3, 223-251. Oxford: Oxford University Press.

RombandeEva = Ромбандеева, Евдокия Ивановна. 1979. Синтаксис мансийского (вогульского) языка. Москва: Наука.

RombandeEva, Evdokija Ivanovna. 1984. Wogulische Syntax (Ars Ob-Ugrica. Arbeiten auf dem Gebiet der obugrischen Sprachen, Band 4). München: Schiefer. 


\section{Constituent order in Northern Mansi}

Shannon, Thomas F. 200o. On the order of (pro)nominal arguments in Dutch and German. In Shannon, Thomas F. \& Snapper, Johan P. (eds.), The Berkeley conference on Dutch linguistics 1997: Dutch linguistics at the millennium, 145-196. Lanham: University Press of America.

Siewierska, Anna. 1988. Word order rules. New York: Croom Helm.

Sipöcz, KATAlin. 2016. A manysi ditranzitív igék szintaxisa szemantikai megközelítésből. Jelentés és nyelvhasználat 3. 49-61.

Skribnik, Jelena. 2001. Pragmatic structuring in Northern Mansi. In Seilenthal, Tõnu (ed.), Congressus Nonus Internationalis Fenno-Ugristarum. Tartu 7.-13.8.200o. Pars VI, 222-239. Tartu: Auctores.

SкRIBNIK = Скрибник, Елена Константиновна. 2004. Категории мансийского глагола и актуальное членение предложения. In Храковский, Виктор Самуилович \& Володин, Александр Павлович (eds.), Типологические обоснования в грамматике: К то-летию проф. В.С. Храковского, 445-458. Москва: Знак.

Song, JAE Jung 2012. Word order. Cambridge: Cambridge University Press.

SosA, SACHIKO. 2017. Functions of morphosyntactic alternations, and information flow in Surgut Khanty discourse. Helsinki: University of Helsinki. (Doctoral dissertation.) https://helda.helsinki.fi/handle/10138/183285

TAylor, JoHn R. 1996. Possessives in English: An exploration in cognitive grammar. Oxford: Clarendon Press.

Vilkuna, MARIA. 1989. Free word order in Finnish, its syntax and discourse functions (Suomalaisen Kirjallisuuden Seuran Toimituksia 500). Helsinki: Suomalaisen Kirjallisuuden Seura.

Vilkuna, Maria. 1995. Discourse configurationality in Finnish. In É. Kiss, Katalin 1995 (ed.), Discourse configurational languages, 244-268. Oxford: Oxford University Press.

ViRTANEN, SUSANNA. 2013. Informaatiorakenteen vaikutus suoran objektin merkintään mansin itämurteissa. Journal de la Société Finno-Ougrienne 94. 293-335. https://doi.org/10.33340/susa.82601

Virtanen, Susanna. 2014. Pragmatic direct object marking in Eastern Mansi. Linguistics 52(2). 391-413. https://doi.org/10.1515/ling-2013-0067

Virtanen, Susanna. 2015. Information structure in Eastern Mansi: An information structural approach. Helsinki: University of Helsinki. (Doctoral dissertation.) https://helda.helsinki.fi/handle/10138/152802

Virtanen, Susanna. 2016. Fokusmerkintä mansin kielen itämurteissa. Folia Uralica Debreceniensia 23. 293-304.

http://finnugor.arts.unideb.hu/fud/fud23/17_virtanen_susanna.pdf

VAN DER WAL, Guenever Johanna. 2009. Word order and information structure in Makhuwa-Enahara. Utrecht: Netherlands National Graduate School of Linguistics. (Doctoral dissertation.)

https://scholarlypublications.universiteitleiden.nl/handle/1887/13845

WAgner-Nagy, BeÁtA. 2011. On the typology of negation in Ob-Ugric and Samoyedic languages (Mémoires de la Société Finno-Ougrienne 262). Helsinki: Finno-Ugrian Society.

Zepter, Alexandra. 2003. Phrase structure directionality: Having a few choices. New Jersey: Rutgers, The State University of New Jersey. (Doctoral dissertation.) https://rucore.libraries.rutgers.edu/rutgers-lib/38429/PDF/1/play/ 
Appendix: Frequency of syntactic functions in my data in the $9+1$ slots.

\begin{tabular}{lrrrrrrrrrr}
\hline Role & O & 1 & 2 & 3 & 4 & 5 & 6 & 7 & 8 & 9 \\
& & S & Temp & Loc & Man & Adv2 & D & S2 & Focus & V \\
\hline Verb & 1 & 2 & - & - & - & - & 2 & - & 1 & 624 \\
Nominal predicate & - & - & - & - & 8 & - & - & - & 49 & 10 \\
Subject, active & - & 245 & - & - & - & - & - & 87 & - & - \\
Subject, passive & - & 56 & - & - & - & - & - & 33 & - & - \\
Temporal adverbial & 20 & - & 115 & - & - & 17 & - & - & 6 & - \\
Locational adverbial & 4 & - & - & 128 & - & 23 & - & - & 10 & - \\
Manner adverbial & 10 & - & - & - & 123 & - & - & - & 32 & - \\
Directional adverbial & - & - & - & 1 & 2 & 5 & 76 & - & 12 & - \\
(lative or ablative) & & & & & & & & & \\
Other adverbials & 11 & - & - & 2 & - & - & - & - & 4 & - \\
DO & - & 1 & - & - & 4 & - & 54 & - & 48 & - \\
IO & - & - & - & - & - & - & 5 & - & 24 & - \\
IO $_{\text {LAT }}$ & - & - & - & - & - & - & 22 & - & 3 & - \\
Agent adverbial & - & - & - & - & 5 & - & - & - & 9 & - \\
Infinitive & - & - & - & - & 2 & - & 2 & - & 94 & 3 \\
Negation & - & - & - & - & - & - & - & - & 25 & - \\
\hline
\end{tabular}

a. In this table, the placement of infinitives and some other functions may overlap. In such cases, both an infinitive and a DO, a directional or some other adverbial are placed in the same slot. Consequently, both are calculated in the total number of occurrences. This exceptional arrangement concerns only infinitives, for further details see Section 5.5. 